\title{
Schilling von Canstadt and His Correspondence with Julius Klaproth in the IOM
}

Abstract: The paper documents the relationship between the inventor printer and collector of Oriental books Schilling von Canstadt and the Orientalist Julius Klaproth by means of their extant correspondence. Both travelled to the Russian-Mongolian border and acquired books, both were connected with the Academy of Sciences in St. Petersburg and Paris, the centre of Oriental Studies. Klaproth's focus were the history and geography of East and Central Asia, Schilling's book collecting and quality printing. Small wonder they got in close contact - Schilling profited from Klaproth's Orientalist expertise, Klaproth from Schilling's rich library and his experience with printing. The letters show an alienation at some point, which was never redressed nor explained, even though the relationship was not severed.

Key words: Schilling von Canstadt, Paul Ludwig (1786-1837); Klaproth, Heinrich Julius (1783-1835); history of printing Oriental scripts; history of Oriental Studies

\section{Paul Schilling von Canstadt}

Traditionally, Orientalists were often theologians, explorers and linguists. It is rather rare to see a scientist and inventor among them: Schilling von Canstadt (1786-1837) was also a pioneer in printing Oriental scripts, a bibliophile and a book collector.

Schilling was born in Reval and received a military education but at the age of 16 he was transferred as an interpreter to the Ministry of Foreign Affairs of the Russian Empire and attached to the embassy in Munich. There he befriended the physician Samuel Thomas Sömmering (1755-1830) who experimented with electricity and was working on a telegraph. Schilling

\footnotetext{
${ }^{1}$ C Hartmut Walravens. Staatsbibliothek zu Berlin, Free University of Berlin
} 


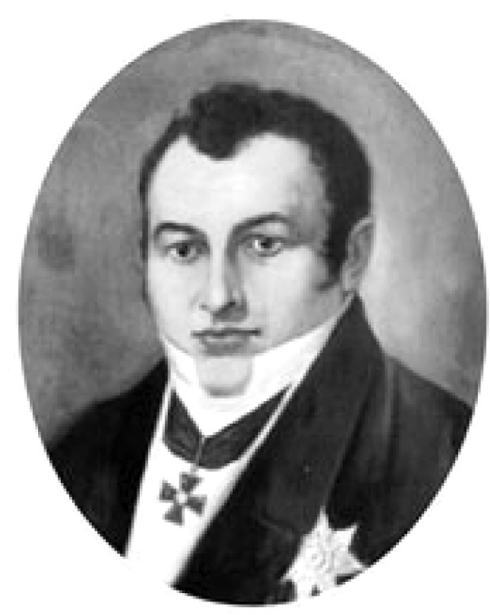

continued these experiments later on and presented an electromagnetic telegraph at the naturalists' conference in Bonn in 1835. As he died soon afterwards it took decades until the priority of his invention became generally known.

His involvement in printing started allegedly when he became dismayed with the large amount of copying necessary for official forms and documents. He suggested to use lithography for this purpose, so he was sent to Munich (lithography had been invented by Alois Senefelder in 1788) to study the technique, and in 1818 he established the first lithographic printing shop in Russia, with the Ministry of Foreign Affairs. He realized that this printing method might also be usefully applied to the printing of Oriental scripts. And indeed, his reproductions of several Chinese texts won the admiration of Sinologists.

We do not know what exactly influenced him to become an Orientalist and book-collector.

At any rate, he was already involved in printing Manchu and Mongol in 1817 as he had a font cut by Friedrich Gass, of the Imperial Mint, who became his assistant. Two years later he had a smaller Manchu-Mongol font cut by Schelter in Leipzig. It was apparently used to print the gospel of St. Matthew, translated into Manchu by Stepan Lipovcov (1770-1841), in 1822. Schilling was also involved in the production of a 4 page sample (printed by Gretsch) of a pentaglot (Chinese, Manchu, Mongol, Latin and Russian) dictionary edited by Pavel Kamenskii (archimandrite Petr); the project was not continued, however, as Kamenskii was sent to China, and there was no Sinologist left in Petersburg to oversee the printing.

In 1841, the academician Marie Félicite Brosset wrote about Schilling's collections: $:^{2}$

«The late Baron Schilling von Canstadt had a declared taste for the literatures of East Asia, a taste which ever grew until the end of his life. By means of occupying himself with them as an amateur, he acquired that

\footnotetext{
${ }^{2}$ Brosset 1841.
} 
bibliophile erudition which guided him in the choice of works and enabled him to make good collections. On the other hand the connections which he formed and which he never stopped to entertain with all the Sinologists of Russia and Europe kept him updated regarding the progress of Chinese literature while his inventive genius led him to search for and to imagine the means for its diffusion. ...

While he occupied himself so actively with these experiments, he by no means neglected his Chinese library which comprised beautiful and good works, choice editions and many manuscript works of the Russian interpreters. When this collection had reached about 252 items he ceded them to the government on the proposition of Prince Lieven, ${ }^{3}$ then Minister of public instruction, in 1830. As the latter had developed a project of organizing Oriental language instruction at the University of St. Petersburg in large, this collection should serve as the nucleus of an annexed library. One notices here among others a good number of copies of the better Chinese and Manchu dictionaries, a magnificent edition of the classics in 24 volumes (185 fascicles), the geographic dictionary in 6 languages, which was often mentioned in the Academy, two copies of the Manchu translation of the famous novel Jin Ping Mei, and many historical and geographical books.

As there was not sufficient space in the University building, all these works were provisionally deposited in the halls of the Asiatic Museum; but after the change of the minister had postponed or rather modified the project of establishing an Oriental faculty, the Academy was instructed by His Excellency the Vice-President that His Majesty had deigned to transfer the ownership of these treasures to the Academy. Thus our collection was at once almost doubled.

Indefatigable in his research, baron Schilling had hardly given away his first collection when he started working on the second: a trip which he undertook in the suite of the Russian mission and a stay of some time at the Chinese border provided him at first with the means, then - the route was set - the missionaries in Peking flooded him with the best literary productions of China; all his activity, his zeal, his resources were directed to this goal and with a perseverance and an extraordinary skill deployed in this sense, he saw himself soon at the head of a new, not only Chinese and Manchu, but also Mongol, Tibetan and polyglot library which certainly

\footnotetext{
${ }^{3}$ Karl von Lieven (1767-1844), 1828-1833 Russian Minister of Public Instruction. Cf. DIEDERICHS 1883.
} 
did not have its equal in any place in the world. I do not want to speak here about Tibetan and Mongolian works, the examination and classification of which is the responsibility of my learned colleague Mr. Schmidt. As to the Chinese works, the new collection was singularly rich in historical, geographical and juridical works. A very beautiful copy of the general statistics of China [= gazetteer, Da Qing yitong zhi], in 300 fascicles; a general history of China from the oldest times to the present, in 77 volumes or 699 fascicles; two copies of the hexaglot geographical dictionary [Xiyu tongwenzhi] and a large number of polyglot dictionaries, Manchu, Chinese, Mongolian; the decrees of the Yongzheng emperor in 50 large vols. or 300 fascicles, many maps and illustrated books, the best Chinese novels, with printed or ms. Manchu translations and among the books published by missionaries, many printed in the Chinese style, books much sought after by amateurs. Such are the most remarkable productions which the second collection brought our Museum. It is ever regrettable that the most precious of the works I have talked about, the Chinese annals, which are so rare to find in one and the same edition, were reclaimed. The Academy proved, by returning them, a lack of interest and a goodwill which will cost it dear. As the finest product of Chinese typography I should not forget to mention here a second copy of the collection of classical books which was present already in the first collection; but this one surpasses the other by being printed on white paper, admirably executed, and stored in 24 wooden boxes, thus testifying to the price attached to such a book by the care given to its conservation.

After the death of the owner on July 25, 1837, the Academy showed its wish that his Oriental library should not become lost to Russia; on the proposition made to Him by H.E. the Minister of Public Instruction and President of the Academy, His Majesty deigned to acquire it from his private funds and to give it as a present to our Museum in 1838. Thus Russia did not loose a treasure amassed by the perseverance of one of her children, and the future Sinologist who will doubtlessly one day want to exploit here the riches of Chinese literature, will only be embarrassed by the choice in the middle of the most abundant resources».

At the time of this report, the Chinese collection of the Museum numbered 1.071 titles; thus it seems to have comprised around 500 titles before Schilling's collections. Considering the quality of the works, the new acquisition was truly remarkable. This gift required a rearrangement and new classification of the whole collection, which was undertaken by Marie Félicité Brosset 
(1802-1880), originally a Sinologist and a disciple of Stanislas Julien in Paris. Brosset went to Russia and became an outstanding specialist for Georgian and Armenian culture. Apparently no other Sinologist was available at the Academy at that time, and so he had to step in. He did his job so well that the collection was from then on dubbed «Brosset Collection» while Schilling's name fell into oblivion. Brosset's catalogue does not give Chinese characters and no description - mainly the titles. Its merit was in the classification of the material. The first collection was described by Isaak Jakob Schmidt in St. Petersburger Zeitung 1830 (no. 88 ff.) while a list of the second collection was also described by Schmidt, on the basis of data provided by archimandrite Iakinf (unpublished).

It may be noted that Schilling made two donations of Tibetan and Mongol books to the Société asiatique in Paris; the collections were later transferred to the Institut de France; they were catalogued by Jacques Bacot and by Louis Ligeti.

August Wilhelm von Schlegel (1767-1845), professor of modern literatures at Bonn University and well-known Indologist, was so charmed by his learned and urbane visitor that he wrote a Sanskrit ode on him which he published in his Indische Bibliothek (2. 1824, 215):

Dich preise ich, o glückbegabter Schilling, und erfrage Dein Wohlsein, denn Du bist der Stirnschmuck unter den Gelehrten im Reiche des Nordlandes. Du vertiefst Dich in das Lesen der Bücher der Bauddha und der Brahmanen; an allen Orten suchst Du Schriften auf, bist aller Sprachen kundig. Du bist das Auge im Lesen alter Schrift, und selbst in mannichfacher Schreibekunst geschickt; im Schachspiel bist Du unbesiegter, auch ohne selbst zuzusehen.

[I praise you, o lucky Schilling, and ask after your wellbeing, because you are the forehead adornment among the scholars of the Northern Empire. You are engrossed in reading the books of Buddha and the Brahmans; in all places you search for scriptures, and you are knowledgeable about all languages. You are the eye in reading old script and well versed in various forms of the art of writing. You are invincible in chess, even without watching yourself]. 


\section{Bibliography on Paul Schilling von Canstadt}

"Necrolog". Das Inland 2. 1837, 535-536.

"Baron Schilling als Gottheit unter den Lama's.". Archiv für wiss. Kunde von Rußland 7. 1849, 192-202.

GuREVICH P.: "Shilling-fon-Kanshtadt, baron Pavel L'vovich". In: Russkii biograficheskii slovar 23. 1911, 276-280.

BACOT, Jacques: "La collection tibétaine Schilling von Canstadt à la Bibliothèque de l'Institut'. Journal asiatique 205. 1924, 321-348.

LIGETI, Louis: "La collection mongole Schilling von Canstadt à la Bibliothèque de l'Institut'. T'oung Pao 27. 1930, 119-178.

YAROTSKII A.V.: “O deiatel'nosti P.L. Shillinga kak vostokoveda”. In: Ocherki po istorii russkogo vostokovedeniia 6. 1963, 218-253.

CHUGUevsKII L.I.: "Iz istorii izdaniia vostochnykh tekstov v Rossii v pervoi chetverti XIX v.”. Strany i narody Vostoka 11. 1971, 280-294.

ASCHOFF, Volker: "Paul Schilling von Canstadt und die Geschichte des elektromagnetischen Telegraphen”. Deutsches Museum. Abhandlungen und Berichte 44. 1976, no. 3 .

WALRAVENS, Hartmut: Zur Geschichte der Ostasienwissenschaften in Europa. Abel Rémusat (1788-1832) und das Umfeld Julius Klaproths (1783-1835). Wiesbaden: Harrassowitz 1999. (183 pp.) (Orientalistik Bibliographien und Dokumentationen 5), 85-100.

"Briefwechsel mit P.S. v. C.”. In: Julius Klaproth: Briefwechsel mit Gelehrten, groBenteils aus dem Akademiearchiv in St. Petersburg. Wiesbaden 2002, 13-42.

WalRaVens, Hartmut: "Konnte der Drucker und Verleger Karl Tauchnitz Tibetisch?”. In: Aus dem Antiquariat 2, 2004, 83-91.

WalRaVEns, Hartmut: "Schilling von Canstadt, Paul”. In: Neue Deutsche Biographie 22. 2005, 768-769.

Russkie voennye vostokovedy do $1917 \mathrm{~g}$. Biobibliograficheskii slovar. Moscow: Vostochnaia literatura 2005, 268-269.

ChuguevskiI L.I.: Shilling Pavel Lvovich [Obozrenie fonda No. 56 Archiva vostokovedov SPbF IV RAN]. Vstuplenie i publikastiia I.F. Popovoi. Pis'mennye pamiatniki Vostoka 4. 2006, 249-262.

\section{Heinrich Julius Klaproth}

Life and works of Julius Klaproth (Berlin 11 Oct. 1783-28. Aug. 1835 Paris) have been dealt with extensively (see Bibliography below) so that a brief sketch may suffice to recall the most important dates of his career. Klaproth was the son of Martin Heinrich Klaproth, chemist in Berlin and member of the Prussian Academy of Sciences. Among his achievements was the 
discovery of four chemical elements, among them uranium. Young Klaproth was supposed to follow in his father's footsteps but he spent his time at the Royal Library, teaching himself Chinese quite successfully. His father's attempts to win him for the natural sciences were in vain. Young Klaproth convinced a publisher to publish his journal Asiatisches Magazin (Weimar 1802). In 1805 he was invited by the Polish historian Jan Potocki to join an embassy destined to China, under the leadership of Count Jurii

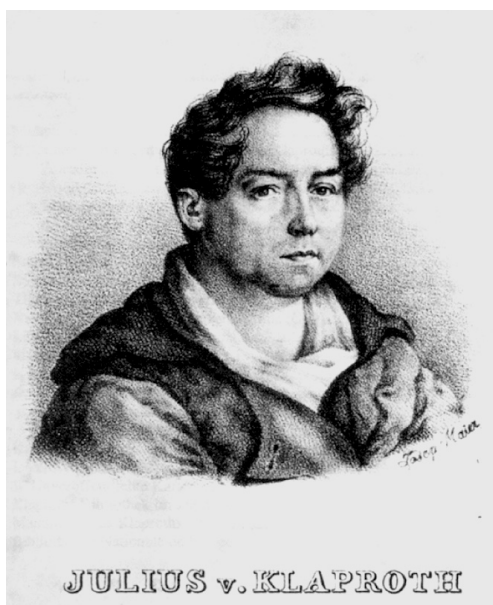
Golovkin. When this enterprise had to be given up in Mongolia, Klaproth became a member (adjunct) of the Russian Academy of Sciences and was sent on a trip of exploration to the Chinese border. After being promoted to extraordinary academician he explored the Caucasus (1808-1809). Afterwards he catalogued the Chinese and Manchu books of the Academy Library; apparently St. Petersburg was not attractive for him as the centre of Orientalists was Paris. Back in Germany he won the protection of the Humboldt brothers, the minister Altenstein and the Prussian king and was appointed professor of Asiatic Languages at the newly established University at Bonn (1816). This did not please Klaproth because he saw no way to publish his works in the Oriental field in a sleepy country town - Paris offered a large Chinese and Manchu book collection, Orientalists of the different disciplines and the Imperial (then Royal) Printing-shop; so he made it clear to his mentors that he would only in Paris be able to do satisfactory research and publish the results of it. His protectors finally agreed and allowed him to settle in Paris on a Prussian research stipend. There he was one of the co-founders of the Société asiatique, co-editor of the Journal asiatique, became the friend of the first European professor occupying a chair of Chinese Studies, J.P. Abel Rémusat and published a large number of works, altogether about 300 . He was not only an outstanding Sinologist, he turned out to be an excellent cartographer, created the first typography to print Egyptian hieroglyphs, had a Manchu and a Chinese typography cut, was one of the first scholars to work with Japanese texts, acquired a basic knowledge of Tibetan and Mongolian. He was a feared and relentless critic, and more often than not he was 
right. Thus he fought against I.J. Schmidt's theory that the Uighurs had been of Tibetan stock (they were Turks) and Nikita Yakovlevich Bichurin's, a good Sinologist's, belief in unfounded Chinese theories, against Joseph Hager's belief in his own Chinese scholarship, Weston's Sinological efforts, Langlès' Manchu pretensions and unveiled deficits in Champollion's readings of hieroglyphic inscriptions... He certainly was a very influential scholar with a large European network.

\section{Bibliography on Julius Klaproth}

EYRIÈs, J.B.: "Klaproth, Jules-Henri”. In: Biographie universelle (Michaud) ${ }^{2} 22$. (n.d.), 3-11.

CORDIER, Henri: "Un orientaliste allemand: Jules Klaproth". In: Comptes-rendus. Académie des inscriptions et belles-lettres 1927, 297-308.

WALRAVENS, Hartmut: "Von der notwendigen Unterdrückung der deutschen Universitäten. Der Berliner Universalgelehrte Julius Klaproth und die Königliche Bibliothek". In: Jahrbuch Preußischer Kulturbesitz 31. 1995, 225-249.

Julius Klaproth (1783-1835). Leben und Werk. Wiesbaden: Harrassowitz 1999. X, 230 pp. (Orientalistik Bibliographien und Dokumentationen 3).

KLAProth, Julius (1783-1835): Briefe und Dokumente. Wiesbaden: Harrassowitz 1999. 235 pp. (Orientalistik Bibliographien und Dokumentationen 4).

KORNICKI, Peter: "Julius Klaproth and his works". Monumenta Nipponica 55. 2000, 579-589.

KLAPROTH, Julius (1783-1835): Briefwechsel mit Gelehrten, großenteils aus dem Akademiearchiv in St. Petersburg. Wiesbaden: Harrassowitz 2002. XVII, 216 pp. (Orientalistik Bibliographien und Dokumentationen 18).

WALRAVENS, Hartmut: "Siebold and Klaproth - a «literary friendship»?" In: EAJRS Newsletter 9. 2002, 13-18.

WALRAVENS, Hartmut: "Julius Klaproth - his life and works; with special emphasis on Japan". In: Japonica Humboldtiana 10. 2006, 177-191.

Dictionnaire des orientalistes de langue française. Paris 2008, 541-542 (Patrick Beillevaire, Timur Beisembiev).

SondermanN, Frieder: "Heinrich Julius Klaproth (1783-1835) und Johann Caspar Horner (1774-1834) über Kontakte zwischen Europa und Asien”. In: Journal of human informatics 13. 2008, 59-86.

WALRAVENS, Hartmut: "Julius Klaproth, Stanislas Julien et les débuts de la sinologie européenne". In: La Chine dans l'espace Franco-Allemand au XIXe siècle. Une certaine Chine entre France et Allemagne au XIXe siécle. Paris: Actes Sud 2012, 145-155.

WALRAVENS, Hartmut: "Julius Klaproth, Stanislas Julien und die Anfänge der europäischen Sinologie". In: Mitteilungsblatt DCG 55. 2012, 51-58. 
WALRAVENS, Hartmut: "Ergänzungen zum Schriftenverzeichnis Julius Klaproth (1783-1835)". In: Auskunft [Hamburg] 33. 2013, 73-90.

FRIEDER, Sondermann Ernst: “Julius von Klaproths Briefe an Joseph von Hammer". In: Tôhôgakuin daigaku yôgakubu ronshû 148. 2014, 19-53.

\section{The Letters}

After Schilling had been appointed head of the first lithographic printingshop in Russia in 1818, he impressed his contemporaries with a reprint of a popular Chinese textbook, the Three Character Classic Sanzijing 三字經 (1819) which he circulated to a number of experts, such as Jean-Pierre Abel Rémusat who held the first chair of Chinese Studies in Europe, and Julius Klaproth, also in Paris, who was supported by a Prussian research grant on the recommendation of the Humboldt brothers. Letter 1 and 2 praise the booklet as an outstanding beautiful achievement of printing technique. Klaproth assumed that Schilling was the originator of the apparently anonymous shipment and that the printing was done in collaboration with the wellknown printer Karl Tauchnitz of Leipzig. ${ }^{4}$ He sent Schilling the first fascicle of his Supplement to the Paris Chinese Dictionary.

Letter 3 is a cover note to the communication of the Sociéte asiatique that Schilling was elected foreign Associate of the Society. The following note enquires after a map in the possession of the Italian collector Onorato Martucci - whether it is complete, of which date, and whether it is in Chinese only, or in Chinese and Manchu; Schilling was in London at that time, apparently the Martucci was there, too. In another letter (in the Academy Archives) Klaproth, after his own visit to London in 1825, gave a negative evaluation of the map and Martucci's books. It is noticeable that Klaproth addressed Schilling «Monsieur le Baron» before, and now he switched to «Dear Friend». Letter 5 reports on Klaproth's recent and current works and shipments of some of his publications. He apologizes for having kept a copy of the geographical dictionary Xiyu tongwenzhi which he had borrowed from Schilling, longer than had been agreed. Apparently Schilling was unhappy about this, the relations seem to have cooled somewhat and Klaproth reverted to the address «Theuerster Herr Baron». He excused his behaviour by stating that he needed extra time for translating the whole dictionary. For Klaproth, Schilling was an important contact. While he was pleased to live

\footnotetext{
${ }^{4}$ The latter was never confirmed.
} 
in Paris with a good Oriental library and an efficient Oriental printing-shop at hand, he still needed more material, and usually Schilling owned it. Thus the letters always contain requests for books and information, like the repeated (and apparently never filled) wish for the supplement to the Manchu Dictionary (Manju gisun be buleku bithe) and the explanation of works in the annals of the three foreign dynasties Jin, Liao and Yuan 金遼元國三史 語解 Jin Liao Yuan guo san shi yujie. Klaproth was wondering why Schilling was hardly ever answering his letters, and communicated that his colleagues, especially Rémusat, had the same experience.

Klaproth enquired also after the situation of the monk Hyacinth (Iakinf), the former head of the Russian Ecclesiastical Mission in Peking, who had been banished to a term in a lonely monastery, on account of his worldly behaviour in Peking. Schilling indeed managed to claim Iakinf's services for his work, e.g. for the official trip to Kiakhta where the monk's outstanding language skills and experience in things Chinese proved very beneficial. The close cooperation between Schilling and Iakinf may have contributed to the cooling of his relations with Klaproth: The latter kept pointing out Iakinf's mistakes, which led to a literary fight by means of pamphlets published by both sides. The same happened with Isaak Jakob Schmidt, the founder of Mongolian Studies in Europe and godfather of Tibetan Studies. Klaproth insisted that he unveiled and criticized the others' mistakes not for personal reasons but in the interest of scholarship: «If he [Iakinf] publishes something in the future he would do well to compare the pieces with the [original] texts beforehand, and pass them on to sensible people so that he will not again have dates grown in Lesser Bukharia, and say that the Bukharians did not have a first day of the first month» (Letter 5).

In the following letter information is given on a change of the publisher of the Journal asiatique, vol. 3 of Klaproth's Mémoires is currently in press, and a large map of China is being engraved. Klaproth is expecting a dictionary of the Chinese concept style, which he ordered for Schilling from Canton.

Klaproth reports on his conciliatory effort to have Iakinf elected foreign member of the Société asiatique, which, however, met the opposition of Rémusat, as Iakinf had just released another pamphlet against Klaproth who now comments on individual items in the critique. He repeats his request to let him borrow the Jin Liao Yuan guo san shi yujie in which the authors attempted to explain all Central Asian names on the basis of the Mongolian language, a futile and senseless endeavour the results of which were incorpo- 
rated in the Da Qing yitongzhi 大清一統志. He also defends his studies on the hieroglyphs which had found wide acclaim in the journals - even if Schilling is reported to have said «that Klaproth liked to write about matters he did not know anything about».

There are a number of notes (mostly undated) and short communications, several of which refer to St. Petersburg collections or list his requests.

The file contains also a letter from Klaproth to the Indologist Horace Hayman Wilson (1833) and a review (by Schilling?) of Klaproth's Examen critique des travaux de feu M. Champollion sur les hiéroglyphes.

All these communications offer stimulating reading; they contain a cornucopia of details that throw light on the work of two outstanding scholars. They fill gaps in the Klaproth file of the Academy Archives in St. Petersburg, which was published in KLAPROTH 2002b, 13-36:

$\begin{aligned} 1 & \text { 9. Dec. } 1821 \text { from Schilling } \\ 2 & \text { 10. April } 1822 \\ 3 & \text { 25. Sept. } 1822 \\ 4 & \text { 16. Febr. } 1823 \\ 5 & \text { 6. April } 1824 \\ 7 & \text { 11. Oct. } 1824 \\ 8 & \text { 26. Dec. } 1824 \\ 9 & \text { 13. Jan. } 1825 \\ 10 & \text { 9. Sept } 1825 \\ 11 & \text { 10. Sept. } 1825 \\ 12 & \text { 24, Oct. } 1825 \\ 14 & \text { 13. Aug. } 1826 \\ 16 & \text { 11. Febr, } 1827 \\ 17 & \text { 24. May } 1828 \\ 18 & \text { n.d. } \\ 19 & \text { n.d. } \\ 20 & \text { n.d. } \\ 21 & \text { n.d. } \\ 22 & \text { n.d. } \\ 23 & \text { n.d. } \\ 24 & \text { 10. Aug. } 1834\end{aligned}$


Letters of Klaproth to Schilling in the Archives of Orientalists of IOM, RAS:

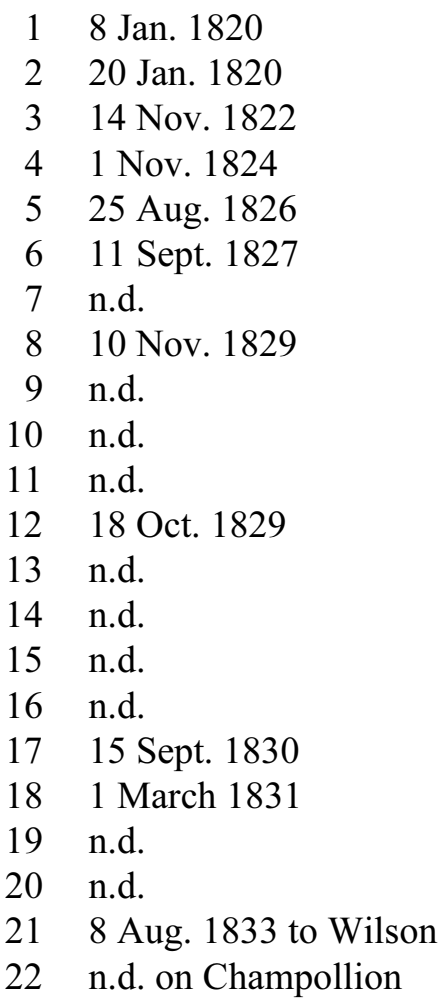

$1[1820]$

A Monsieur

Monsieur P.B.S. de C- $\mathrm{t}$

Editeur du San tsi king

Paris ce 8 Janv. 1820

Mon cher ami, ou mon cher Monsieur P.B.S. de C-t

Je Vous remercie de tout mon cœur pour les belles etrennes, que Vous m'avez envoyé. Votre San-tsu-king ${ }^{5}$ égale en beauté les impressions les

${ }^{5}$ The Sanzijing 三字經, The Classic of Three Characters, was used as educational text for the instruction of children in traditional China. It is usually attributed to Wang Yinglin 王應 麟 (1223-1296). Baron Schilling printed a remarkably beautiful edition which is praised in the letter. 
mieux soignées du palais impériale de Pe king, et principalement celui que Vous avez reçu de Mr. Huttmann. ${ }^{6}$ La fable d'un amateur qui étudie depuis deux ans seulement le Chinois aurait pu prendre; si je n'avais pas trouvé dans la lettre anonyme une expression qui Vous est propre, sans que Vous le remarquez. Savoir «Je ferai voir à Messieurs les Anglais» etc. C'est Votre expression qui Vous trahit. Neanmois j'ai repondu à Mr. Firmin Didot ${ }^{7}$, comme Vous l'avez désiré. Savez Vous ce que je pense: Vous avez fait ce San-tsu-king avec Mr. Tauchnitz à Leipzig. Ce sont les caracteres Mantchoux qui se trouvaient dans le paquet de Mr. Rémusat ${ }^{8}$, et qui me paroissent d'etre gravés sur mes dessins, qui me font penser cela.

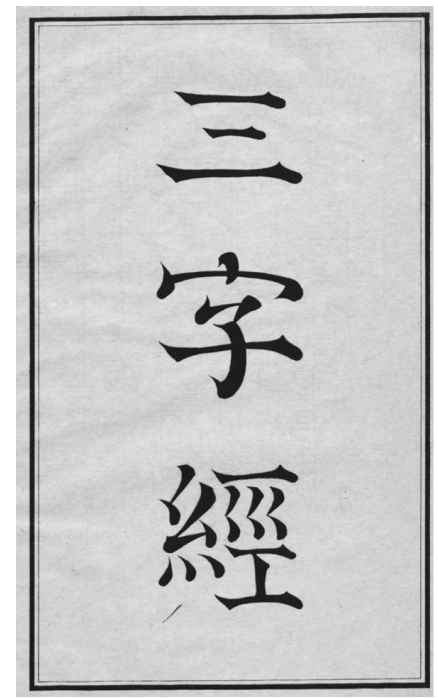

En tout cas, Votre devise etait: A dieu mon ame, ma vie au Roi, ma cœur aux dames, l'honneurs à moi, je trouve que personne ne Vous dispenserai pas la derniere partie de cette devise. Votre San-tsu-king est un monument qui doit faire ecrouler (崩) la vanité de Morrison, et de tous les missionaires de la Chine. Si c'est Mr. Tauchnitz ${ }^{9}$ qui a fait le San-tsi-king avec Vous, je Vous prie de lui dire mille choses flatteuses de ma part.

Vous devez avoir reçu la premiere partie de mon Supplement, ${ }^{10}$ c'est-àdire les bonnes feuilles qui Vous manquaient, et la chemise de la premiere

\footnotetext{
${ }^{6}$ William Huttmann (9 March 1792 - 3 Oct. 1844), Orientalist, with special interest in Chinese and Manchu. He offered to prepare a translation of the Chunqiu. He served until 1832 as secretary to the Royal Asiatic Society and became a fellow of the Royal Geographical Society. A short biobibliography is ready in ms. See the obituary: ANON 1844.

${ }^{7}$ Firmin Didot (14 April 1764 - 24 April 1836), was a printer, engraver, and type founder. He used stereotype technology to create quality printing at low prices. He was appointed director of the typefoundry of the Imperial Printing-shop in Paris.

${ }^{8}$ Jean-Pierre Abel Rémusat (Paris, 5 Sept. 1788 - 4 June 1832, Paris), studied medicine but taught himself Chinese and was appointed to the first chair of Chinese Studies in Europe in 1814. Together with his friend Klaproth he founded the Sociéte asiatique in 1821; he published extensively and may justly be regarded, with Klaproth, as the founder of scholarly Sinology. Cf. WALRAVENS 1999.

${ }^{9}$ Carl Christoph Traugott Tauchnitz (Großbardau 1761-1836 Leipzig), printer and publisher at Leipzig, known for the introduction of stereotype technology in Germany. Schilling was in contact with Tauchnitz, at least later on when in 1835 he induced him to print two Tibetan texts. Cf. WALRAVENS 2004.

${ }^{10}$ KLAPROTH 1819 . The introduction to this work was written by Rémusat.
} 
livraison. Tachez d'avoir le Novembre et Decembre du Journal des Savans, dans lequel Vous trouverez l'analyse de mon ouvrage par Remusat. ${ }^{11}$ Je Vous souhaite toute Sorte de bonheur 後福前福 pour la nouvelle année qui nous commençons, et dans laquelle je compte de voir enfin paroître un des ouvrages que Vous preparez avec tant d'assiduité. Les mêmes felicitations pour Madame et pour Catarino. ${ }^{12}$

V. sincere ami

JHKlaproth

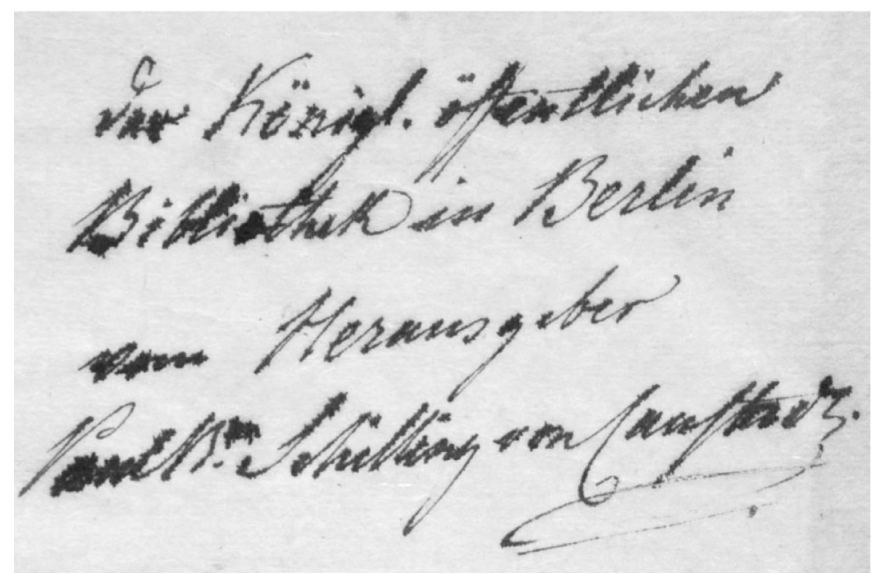

Schilling's dedication to the Berlin Royal Library

*Je reconnois avec assurance que les caracteres du San-tzu-king dont il est question ici, n'ont aucune ressemblance avec ceux de l'edition merveilleuse publiée par M. le Baron de Schilling. Antonio Montucci ${ }^{13}$

\footnotetext{
${ }^{11}$ RÉMUSAT 1819.

${ }^{12}$ Possibly Catarino Cavos (1775-1840), Italian opera composer and conductor in St. Petersburg. He was married to Camilla Baglioni (1773-1832), a renowned opera singer.

${ }^{13}$ Antonio Montucci (Siena, 22 May 1762 - 25 March 1829 Siena), Doctor of Law, from Siena, made his living as Italian master, for a while on the estate of the porcelain manufacturer, later at the Berlin and the Dresden court. He earned some Chinese from two Chinese in Britain but was largely self taught. He pursued the idea of editing and printing a comprehensive Chinese dictionary, and for this purpose he had appr. 18.000 wooden types engraved. He was never given a chance to practice his expertise as the European courts, in spite of their interest, had other more urgent worries. Only Napoleon had a dictionary printed in $1813-$ he hired Desguignes fils (1759-1845) who had worked in Canton as a merchant and who saw Father Basilio Brollo's (1648-1704) outdated manuscript through the press. Cf. WALRAVENS 1992b.
} 
$2[1820]$

\section{Monsieur}

Depuis trois jours je suis en admiration devant Votre bel ouvrage, qui pour la correction et pour l'elegance de l'éxécution égale tout ce que j'ai vu de plus parfait imprimé en Chine même; et qui laisse loin derriere lui les essais qui ont parut jusqu'à présent en Europe et aux Indes. Sans le timbre sur de la première page qui envelloppait l'exemplaire, que Vous m'avez fait l'honneur de m'envoyer, je n'aurais jamais cru que l'ouvrage fut imprimée (!) en Europe.

Ce que Vous nommez, Monsieur, le dictionnaire Impérial est vraisemblablement le Khang-hy-tsu-tian ${ }^{14}$; mais permettez moi de Vous observer, que Vos caractères ne sont pas tous près dans ce tresor de la langue Chinoise p.e. le mot meng y est ecrit de la maniere suivante 孟 et chez Vous 温. Du reste ce n'est pas une faute mais une difference de style.

Quant à la gravure de Vos caracteres, ils me paraissent d'etre executés en bois, et je ne vois pas que Vous ayez polytypé par la clissage le même lettre quand elle revient plusieurs fois. Le San tsu king contient 1068 caractères Chinois.

Pour les faire graver en bois, à raison de trente sols par pièce: cela occasionnerait une depense de 1602 francs. En se servant du polytypage cette somme se reduirait peut-être à 1200 fr. Un artiste, graveur en bois, peut executurer jusqu'à quinze caracteres per jour. Il lui faudrait donc 71 jours pour achever 1068 caracteres. Vous me ditez, Monsieur, que Votre procédé est peu couteux et expeditif; votre gravure doit donc couter beaucoup moins; en cas que Vous la faitez executer à Paris ou en France; car dans l'etranger ces sortes de travaux sont à meilleur compte.

Tout cela n'empêche pas, que je Vous ne felicite de la superbe execution du San-tsu-king, qui doit même etonner les Chinois, qui le verront. Mon seul desir est d'avoir bientôt l'honneur de connaître Votre nom, et de me mettre en correspondance directe avec un propagateur si zélé de la litterature Chinoise en Europe.

Agréez en attendant l'assurance de la consideration très-distinguée avec laquelle j'ai l'honneur d'etre

Monsieur

Paris ce 20 Janv. 1820 Votre très humble et très obeissant serviteur JHKlaproth

Rue Coquillière Nr. 23

${ }^{14}$ The Kangxi zidian 康熙字典, compiled under the ægis of the Kangxi emperor became a standard dictionary which featured 214 radicals (or keys) which are in se still today. It was published in 1716 and comprises approximately 47.000 characters. 
3 [1822]

Monsieur le Baron

J'ai l'honneur de Vous envoyer ci-jointe une lettre du Secretaire de la Société Asiatique, par laquelle la Société Vous prie d'agréer le choix qu'elle a fait de Vous, pour etre un de ses associés etrangers.

Je Vous prie de recevoir avec indulgence le petit ecrit de ma façon qui accompagne ces lignes, et je saisis cette occasion pour Vous rapeller les demandes de ma derniere.

J'ai l'honneur de Vous réiterer l'assurance des sentiments inalterables avec lesquels je suis

Monsieur le Baron

Paris ce 14 Novembre 1822 . Votre très humble et très obeissant Serviteur JHKlaproth

$4[1824]$

Paris d. 1. Nov. 1824

Lieber Freund

Ihren Brief und auch die drei Paquete für Mlle Millet ${ }^{15}$ habe ich richtig erhalten. Da kurz darauf ein anderer Russischer Courrier von London angekommen ist, so habe ich die Hoffnung aufgegeben Sie sobald hier zu sehen. -

Der dritte Band von Morrison ${ }^{16}$ für Remusat ist nun hier angekommen, geben Sie sich also weiter keine Mühe ihn von Morrison zu bekommen. Wir sind nun quitt.

Sie würden mir einen großen Gefallen erzeigen wenn Sie die Charte von Martucci ${ }^{17}$ genau in Augenschein nähmen und mir mit nächsten eine Notiz davon gäben. Erlauben Sie mir folgende Fragen.

1. Ist sie complêt?

2. Von welchem Jahre?

3. Ist sie chinesisch und mandshuisch, oder nur chinesisch.

4. Ist sie in der geraden oder schrägen Projektion

\footnotetext{
${ }^{15}$ Not identified.

${ }^{16}$ MORRISON 1815-1823.

${ }^{17}$ Onorato Martucci (1774-1846), merchant, traveller and collector. He established a Chinese Museum in Rome, which he sold to the King of Bavaria. Cf. WALRAVENS 1984.
} 
Thun Sie mir auch die Gefälligkeit für mich einen schwarzen Schleyer für 1 oder 1 1/2 Guineen zu kaufen. Ich hatte ihn Madame Doulx ${ }^{18}$ von London mitzubringen versprochen, habe es aber vergessen.

Sie erhalten anbei was von Schmidt ${ }^{19}$ fertig ist.

In der Hoffnung Sie baldigst gesund und froh wieder zu sehen, mit freundschaftlicher Hochachtung der Ihrige

JHKlaproth

5 [1826]

Paris d 25 Aug. 1826

5 Rue d'Amboise

Sie erhalten anbei, theuerster Herr Baron, ein neues Stück des Asiatischen Journal $^{20}$, sowie auch das für Herrn Prof. Fraehn ${ }^{21}$. Nur mit Mühe habe ich es dahin bringen können, daß die Sendung des letzteren so wie die der Schmidtschen ${ }^{22}$ Exemplare, unterdrückt worden ist. Sie wissen daß die As. Gesellschaft nur 200 Ex. vom Journal erhält, und diejenigen, welche sie über diese Zahl braucht, bezahlen muß. Da nun an 200 Mitglieder sind, so hat sich die Commission des Journals genöthigt gesehen, die mehrsten, bisher gratis gegebenen, zu unterdrücken.

Ich lege auch das 2te Heft meines Magazins ${ }^{23}$ bei. Ferner habe ich für Sie das Essay sur le Pali ${ }^{24}$ für 6 fr. gekauft, weil ich glaubte es würde Sie interessiren. Die Supplemente zur Japanischen Grammatik ${ }^{25}$ und den 2ten Band

${ }^{18}$ Madame Doulx is mentioned in a letter to Ladislaus Endlicher as owner of two Japanese dictionaries. Cf. WALRAVENS 2002b, 45.

${ }^{19}$ KLAPROTH 1824.

${ }^{20}$ Journal asiatique, the official journal of the Société asiatique.

${ }^{21}$ Christian Frähn (Rostock, 4 June 1782 - 28 Aug. 1851, St. Petersburg), Orientalist numismatician, professor of Oriental studies at the University of Kazan; in 1818 he became the director of the newly established Asiatic Museum in St. Petersburg. Cf. KLEnZ 1904.

${ }^{22}$ I.e. Isaak Jakob Schmidt (Amsterdam, 14 Oct. $1779-8$ Sept. 1847, St. Petersburg), started his career as a merchant in the Moravian settlement of Sarepta, on the Volga, where he learnt Calmuck. This enabled him later on to translate the Bible into both Kalmuck and Eastern Mongol. He became the founding father of Mongol studies in Europe and a keen promoter of Tibetan studies. Cf. WALRAVENS 2002a.

${ }^{23}$ KLAPROTH 1825/26.

${ }^{24}$ LASSEN 1826.

${ }^{25}$ LANDRESSE 1826. 
meiner Memoires, der sich im Umschlage des Tung wen tschi ${ }^{26}$ findet, bitte ich von mir geneigst [!] anzunehmen. Das dritte Heft des Magazins ${ }^{27}$ wird in 8 Tagen fertig werden. Es enthält einen Theil der Beschreibung von Tubet, die ich aus dem Chinesischen übersetzt habe. Die Tableaux ${ }^{28}$ sind fertig, aber die Charten noch nicht alle illuminirt. Meine Reise nach London

[One page is apparently missing in the original]

ein Geschwür am Schenkel, das mich 2 Monate am Sitzen hinderte und das Ausziehen (weil da wo ich wohnte gebaut werden soll) haben mich in meinen Arbeiten sehr aufgehalten.

Ich wiederhole Ihnen meine Entschuldigungen, daß ich das Thung wen tschi $^{29}$ länger behalten habe als Sie es wünschten. Ich habe es ganz übersetzt. Meine Übersetzung enthält über 200 Folio-Seiten. Wenn Sie nicht mehr böse sind, so bitte ich Sie, meinem gehorsamsten Ansuchen Gehör zu geben, und mir auf 3 oder 4 Monate das 金遼元國三史語解 (so ist der Titel, wenn ich nicht irre) zu leihen. Da ich einmal mir die Mühe gegeben das Thung wen tschi zu übersetzen, so würde mir es sehr angenehm seyn auch dieses Werk zu vergleichen. Es würde mir bei der Herausgabe meiner Charten, und dem dazu gehörigen Texte von großem Nutzen seyn. Ich verspreche Ihnen es nicht länger als 4 Monate zu behalten. Thun Sie mir die Freundschaft es zu schicken. Sie wissen daß ich Ihre Güte bei jeder Gelegenheit, mit Dank, öffentlich anerkenne.

Von Rémusats Chinesischen Roman ${ }^{30}$ wird der zweite Band jetzt gedruckt.

Hat man noch keine Aussicht den Archimandriten ${ }^{31}$ aus dem Kerker zu ziehen? Ich finde, daß die von Timkowski mitgetheilten ${ }^{32}$, und von jenem

26 御製西域同文志, i.e. the geographical dictionary of the Western Regions; this identification is supported by the receipt for this work as printed in WALRAVENS 2002b, 20 .

${ }^{27}$ KLAPROTH $1826 \mathrm{a}$.

${ }^{28}$ KLAPROTH 1826 b.

29 同文志, v.s.

${ }^{30}$ RÉMUSAT 1826.

${ }^{31}$ Iakinf (i.e. Nikita Yakovlevich Bichurin) (27 Aug. 1770 - 11 May 1853). The monk headed the Russian Ecclesiastical Mission in Peking but was released from this responsibility because of an unbecoming, lascivious lifestyle. He was sentenced to a prison term by an Ecclesiastical Court but then released and became Russia's foremost Sinologist of the time. He served as Schilling's interpreter when he was sent on a mission to the Russian-Chinese border. Cf. WALRAVENS 1988.

${ }^{32}$ In: TimKovski 1824. - Timkovskii (Poltava Gvt. 23 May, 1790 - Febr. 9, 1875), official in the Roads Department, led the Russian Ecclesiastical Mission to Peking in 1820. After his return to Russia, he became department head in the Asiatic Department of Ministry of Foreign Affairs, and from 1830-1836 he served as consul in Moldavia. Apparently it is owing to his strong support that the monk Iakinf was released from prison and enabled to resume his scholarly work. Cf. MunKuEv (n.d.); SKACHKOV 1875. 
übersetzten Stücke, viele Mißgriffe enthalten, die ich bei der Französischen Ausgabe $^{33} \mathrm{zu}$ bemerken, genöthigt gewesen bin. Wenn er ins Künftige etwas herausgiebt, so wird es wohlgethan sein, die Stücke vorher noch einmal mit dem Texte zu vergleichen, und sie verständigen Leuten $\mathrm{zu}$ communiziren, damit er nicht wieder Datteln in der kleinen Bucharei wachsen lasse, und nicht sage, die Bucharen hätten keinen ersten Tag im ersten Monate.

Wenn Sie mir einige von den, an Herrn v. Turgeneff ${ }^{34}$ gegebenen, Georgischen Desideratis verschaffen können, werden Sie mich sehr verbinden. Darf ich auch an die Beschreibung von Peking, und ans Supplement zum Mandshu Lexicon ${ }^{35}$ für mich erinnern? - Was haben Sie für Florenz ausrichten können? ${ }^{36}$

In der Hoffnung einer baldigen gütigen Antwort verharre ich mit freundschaftlicher Hochachtung

Ihr gehorsamster Diener

JHKlaproth

Ich beschwöre Sie, mir umgehend ein oder 2. Exemplare des Tatarischen Abulghasi zu schicken, der längst fertig ist. ${ }^{37}$

$6[1827]$

Paris d. 11 Sep. 1827

5 Rue d'Amboise

Ich erfahre so eben daß heute ein Russischer Courier nach St. Petersburg abgeht, und benutze diese Gelegenheit mich wieder bei Ihnen in Erinnerung zu bringen. Weder ich, Remusat und andere Ihrer hiesigen Freunde begreifen Ihr vollkommenes Stillschweigen. Wäre ich der einzige dem Sie nicht schrieben, so würde ich glauben, Sie wären noch böse, wegen des zu späten Empfangs des Thung wen tschi, da aber niemand von Ihnen eine Sylbe erhält, so kann ich dieser Meinung nicht seyn. Da die Erfahrung gelehrt hat, $\mathrm{da} ß$ die Paquete für Sie auf der hiesigen Gesandtschaft liegen bleiben, so weiß ich jetzt kein Mittel Ihnen etwas sicher zu übersenden. Es ist auch

\footnotetext{
${ }^{33}$ TIMKOvskil 1827.

${ }^{34}$ Possibly Sergei Ivanovich Turgenev (1790-1827, Paris) who served as diplomat in Paris and in Constantinople.

${ }^{35}$ Possibly the Manju gisun be niyeceme isabuha bithe of 1786.

${ }^{36}$ It is not explained what Schilling's goal was in Florence. From the Academy Archives part of the files it is obvious that Klaproth had asked Schilling to take care of something on his behalf, possibly researching something at the Biblioteca Magliabechiana.

${ }^{37}$ FRAEHN 1825.
} 
nichts erschienen was Interesse für Sie haben könnte. Remusats Roman werden Sie durch Baron Merian ${ }^{38}$ erhalten haben, und ich hoffe auch meine beiden Lettres sur les hieroglyphes. ${ }^{39}$ Von Neuigkeiten kann ich Ihnen nichts melden, als daß die Asiatische Gesellschaft Dondey Dupre abgesetzt hat, und das Journal Asiatique, vom 1. Januar an unter dem Namen Nouveau Journal Asiatique zu erscheinen und in der Königlichen Asiatischen [!] Druckerey gedruckt werden wird. Wir haben dabei einen schweren Kampf gegen den immer halsstarriger werden S. de Sacy ${ }^{40}$ auszustehen gehabt, aber mit einer Majorität von 2/3 gegen 1/3 den Sieg davon getragen. Das Asiatische Journal hat nur einen jährlichen Fond von 2000 fr. der angewendet werden kann um nützliche Arbeiten zu machen, statt daß wir früher an D.D. den Druck zur Hälfte bezahlten und ihm 3/4 der Ausgabe gratis überließen.

Ich lasse jetzt den 3 ten Band meiner Memoires ${ }^{41}$ drucken, fertig davon sind 9 Bogen, enthalten Lettres sur la litterature mandchoue, Description du Baikal und den Anfang von Fr. Petrarchas Vocabularium Latino-PersicoComanicum, das im Ganzen 7 Bogen einnimmt. ${ }^{42}$ Seyn Sie so gefällig dieß an Krug ${ }^{43}$ und Frähn zu sagen, denen es interessant seyn wird.

Eine große Charte vom Chinesischen Reiche, wird wahrscheinlich im May des künftigen Jahres fertig seyn. Ich lasse auch eine große Charte vom eigentlichen China in 6 Blättern vom größten Formate stechen, auf der der Grad an 3 Zoll Länge hat, fast in derselben Größe wie Ihre große Chinesische Charte, von der ich eine neue Edition besitze. Ich hoffe vielleicht in einer jetzt für mich in London angekommenen Kiste Chinesischer Bücher das 彙字草 ${ }^{44} \mathrm{zu}$ finden, das ich für Sie in Canton bestellt habe. Die Bücher

\footnotetext{
${ }^{38}$ Andreas Adolf von Merian (Basel, 4 July 1772 - 25 April 1828, Batignolles), Austrian diplomat, since 1812 state councillor in Russian service; his special interest was in comparative linguistics. His friend Klaproth edited his Tripartitum seu de analogia linguarum libellus (Paris 1820) and Principes de l'étude comparative des langues (Paris, 1828). During the last years of his life Merian worked in Paris as diplomatic agent for contributions. Cf. His 1941.

${ }^{39}$ KLAPROTH $1827 \mathrm{a}$, KLAPROTH $1827 \mathrm{~b}$.

${ }^{40}$ Antoine Isaac Silvestre de Sacy (Paris, 21 Sept. 1758 - 21 Febr. 1838, Paris), Professor of Persian at the College de France, curator of Oriental mss. at the Imperial Library in Paris, member of the Institute. Cf. SALMON 1905.

${ }^{41}$ KLAPROTH 1828.

${ }^{42}$ Lettres sur la littérature mandchoue, pp. 1-88; revised republication of Klaproth 1815:pp. 89-108 Description du Lac Baikal; - pp. 113-256. Vocabulaire latin, persan et coman, de la Bibliothèque de Francesco Petrarcha.

${ }^{43}$ Johann Philipp Krug (Halle, Jan. 29, 1764 - June 4, 1844, St. Petersburg), historian, member of the Academy of Sciences in St. Petersburg in 1807, became its chief librarian in 1817. ANON 1903.

${ }^{44}$ Caozi hui, a dictionary of the concept style of Chinese characters.
} 
müssen im Laufe dieser Woche anlangen und ich werde es, wenn es dabei ist, Ihnen mit nächster sichern Gelegenheit übersenden; erinnere Sie dabei aber auch dabei an Ihr Versprechen mir ein Exemplar der Supplemente zum mandshuischen Wörterbuche ${ }^{45}$ zu verschaffen.

Mit vorzüglicher Hochachtung habe ich die Ehre zu seyn

Ihr ganz ergebenster und dienstwilligster Diener

JHKlaproth

7 [n.d.]

Ich hatte total vergessen, daß ich heute früh ein Rendezvous bey Eyriès ${ }^{46}$ habe. Wir müssen daher unsere Zusammenkunft bis morgen verschieben. Ich habe wohl heute beim oder vor Essen die Ehre Sie zu sehen.

Tout à Vous

Dimanche matin. JHKlaproth

A Monsieur

Monsieur le Baron Schilling de Canstadt

Hotel d'Italie

8 [1829]

Paris d. 10 Nov. 1829

5 Rue d'Amboise

Theuerster Herr Baron!

Obgleich es scheint als ob Sie Ihre Freundschaft mir gänzlich entzogen habe[n], so nehme ich mi dennoch die Freiheit, mich durch diese Zeilen wieder bei Ihnen in Erinnerung zu bringen, indem ich mir nicht bewusst bin irgend etwas gethan zu haben was Ihnen unangenehm sein könnte, oder mir Ihre Zuneigung abwenden dürfte. Sollte das aber, ohne mein Verschulden geschehen seyn so bitte ich es великодушный ${ }^{47}$ zu verzeihen.

${ }^{45}$ Probably: Han-i araha Nonggime toktobuha Manju gisun-i buleku bithe. Yuzhi zengding Qingwenjian 御製增訂清文鑒. 1772, niyeceme banjibun. 4 fasc. Cf. WALRAVENS 2014, no. 15 .

${ }^{46}$ Jean-Baptiste Benoît Eyriès (Marseille, 24 June, 1767 - 12 June, 1846, Graville), geographer, since 1805 in Paris where he worked as a prolific writer and translator and members of several learned societies, among them the Société asiatique. Cf. LOUVET 1856.

${ }^{47}$ Generous. 
Ich habe Ihnen mit der Post, sous bande franco Memel, die drei ersten (fehlerhafte Correctur) Bogen der Übersetzung der Beschreibung von Tibet überschickt, und die folgenden durch Courriergelegenheit, muß aber fürchten daß Ihnen diese noch nicht zu Händen gekommen sind. Wenn Sie diese Übersetzung mit dem Russischen und dann mit dem Chinesischen Originale vergleichen wollen, so werden Sie sehen, daß ich viele Unrichtigkeiten des Archimandriten mit Stillschweigen übergangen habe, und mehrere von ihm ausgelassene Stellen, ohne es zu sagen, dem Französischen einverleibt habe. Nun muß ich Ihnen aber einen komischen Vorfall erzählen. Da ich die Dummheit der Leute kenne die von einem Gelehrten verlangen er solle alles wissen, so kam es mir beim Durchlesen eines der letzten Correcturbogen des Werkchens ein, daß meine Anmerkungen dem Archimandriten am Ende in Rußland Schaden thun könnten, was doch ganz und gar nicht meine Absicht war. Ich glaubte diesem Übelstande nicht besser abhelfen zu können, als auf eine ehrenvolle Art eine Anerkennung seiner nicht zu läugnenden Verdienste zu geben, und ging deshalb Sonnabends auf die Bibliothek, um Remusat zu ersuchen ihn, mit mir, in der nächsten Sitzung der Asiatischen Gesellschaft zum Auswärtigen Mitgliede vorzuschlagen. Wie sehr aber war ich erstaunt einen förmlichen Refus zu erhalten. Auf meine Anfrage warum? gab er mir die Antwort. Venez après la bibliotheque chez moi et Vous verrez. Und was zeigte er mir die Broschüre des Archimandriten gegen mich. Ich habe sie bei ihm gelesen und werde darauf nicht anders antworten als in den Noten zu der Beschreibung von Tubet und in meinem Artikel über seine Записки о Монголии. Der Ton den er annimmt ist wirklich lächerlich und ich halte ihn dem beleidigten Priester zu gute. Sie kennen mich genug um überzeugt zu seyn, daß ich meine Arbeiten nicht eines nichtigen Ruhmes willen mache, sondern daß mir die historische Wahrheit die Hauptsache ist, ich kann daher und werde es nie zugeben, daß dieselbe durch Unverstand beeinträchtigt wird, sondern diesen so lange ich lebe zu bekämpfen suchen. Ein lächerlicher Widerspruch ist es wenn Hyacinth sagt ich verstünde assez bien le chinois, und nachher meine Übersetzungen voller Fehler findet, die er aber nicht angibt, denn da wo er seine Übertragung der meinigen gegenüber stellt, sagen wir gewöhnlich dasselbe nur mit anderen Worten. Wo bei mir etwas fehlt war der schlechte Abdruck des Originals das ich 1825 hatte an der Stelle unleserlich, auch fehlten demselben die Vorreden. Erst vor kurzem habe ich ein gutes und vollständiges Exemplar aus Canton erhalten. Das erste war zwar auf schönem weißen Papier aber ein Abdruck der schon alt gewordenen Platten. 
Lächerlich ist der Vorwurf den er meiner mandschuischen Chrestomathie ${ }^{48}$ macht, sie bestehe aus Stücken die schon Leontiew ${ }^{49}$ und Remusat übersetzt hätten. Was Leontiew russisch gegeben haben kann kenne ich nicht. Existirt es aber wirklich so vergleiche man nur meine Übersetzung mit der Seinigen und man wird den Unterschied finden. Dasselbe gilt von der Eloge de Moukden ${ }^{50}$, und das Livre de Recompenses et de Peines ${ }^{51}$ war bereits 1817 abgedruckt, also mehrere Jahr früher als ich Remusat mein Chinesisches Exemplar lieh, aus dem er seine Übersetzung gemacht hat. Auch diese vergleiche man mit der meinigen und man wird sehen daß ich seine Verstöße verbessert und was er ausgelassen hinzugesetzt habe. Mit der Expedition Thsin schi huang ti nach den glücklichen Inseln im östlichen Meere, die ich aus du Halde genommen haben soll, ist er ebenfalls unglücklich, ich habe seit mehr als vier Jahren Du Halde nicht aufgeschlagen. Die Stelle ist aus den Japonischen Chroniquen genommen, und ich werde sie nächstens in einer kleinen Dissertation über jene Expedition, nebst anderen dazu gehörigen, und aus der große Japonischen Encyclopédie ${ }^{52}$ entlehnten, im Journal asiatique abdrucken lassen.

Wenn übrigens Hyacinth glaubt mir durch seine Brochure ein großes Herzeleid gemacht zu haben, so irrt er sich. Ich halte dafür daß der Mann recht gut Chinesisch versteht, aber manche Stellen nicht übersetzen kann weil sie zu dunkel sind, oder weil ihm dazu die nöthigen positiven Kenntnisse abgehen, das ist aber mehr oder weniger der Fall mit allen Europäern die Chinesisch treiben. Übrigens ist er ein unkritischer Kopf, dafür kann er nicht. Er hat auch Unrecht meine Erklärung über seine Mongolische Geschichte so verstanden zu haben als behauptete ich in derselben der Tung wen tschi sei ein unbrauchbares und schlechtes Werk; das ist nicht der Fall, es ist im Gegentheile sehr schätzbar, nur nicht für den Türkischen Theil.

Ich spreche von einem ganz anderen Buche um dessen Mittheilung ich Sie oft vergeblich gebeut habe es ist das 語元金遼 (oder so ungefähr betitelt). In diesem Werke haben die Verfasser gesucht alle Eigennahmen die in der älteren Geschichte Mittelasiens vorkommen aus dem Mongolischen zu erklären, ohne daß die Chinesischen Schriftsteller die Übersetzung dieser Namen gegeben haben, die allein die Richtigkeit der Erklärung beweisen können.

\footnotetext{
${ }^{48}$ KLAPROTH 1828 b.

${ }^{49}$ Leont'ev (1716-1786), Sinologist and Manchurist, prolific translator from Chinese and Manchu. Cf. WALRAVENS 1992a.

${ }^{50}$ АмІот 1770.

${ }^{51}$ Livre de recompenses et de peines, i.e. Tai shang ganying pian 太上感應篇. Rémusat used a Chinese edition with an imperial preface of 1655. Cf. RÉMUSAT 1816.

${ }^{52}$ Kimmô zui 訓蒙圖彙; cf. RÉMUSAT 1827.
} 
Sie können sich ein großes Verdienst um die Lösung der streitigen Punkte in der Mittelasiatischen Geschichte machen, wenn Sie das Buch der Asiatischen Gesellschaft mittheilen, und es deren Examen unterwerfen. Es ist dieses die einzige [15b] Art, um allen dem uncritischen Unwesen auf einmal ein Ende zu machen. Schmidt Mongol. Geschichte ist hier noch nicht angekommen. Aus Deutschland schreibt man mir, daß er jetzt von derselben dasselbe Urtheil in seiner Vorrede fülle, das ich vor mehreren Jahren schon gedruckt habe, daß sie nämlich ein in mehrer Hinsicht unzuverlässiges Werk sey.

Obgleich Sie, geehrter Freund, vor einiger Zeit in St. P. bemerkt haben, daß ich gern über Dinge schriebe von denen ich nichts verstände, so lehrt doch jetzt der Erfolg, daß ich mich hinsichtlich der Hieroglyphen und Champollion nicht geirrt habe. Lesen Sie nur die Artikel, in der London Literary Gazette, im Classical Journal, im Asiatic Journal, in der Quotidienne, im Temps, in den heidelberger Jahrbüchern und in den Italiänischen Journalen, in denen man meinen Observations sur l'Alphabet hieroglyphique $^{53}$ alle Gerechtigkeit widerfahren läßt, und sie als ein Muster der Kritik aufstellt. Ich schreibe Ihnen das nicht aus Eigendünkel, sondern einzig als Antwort auf Ihre mündliche Bemerkung von 1827. Jetzt erst fallen den Leuten die Schuppen von den Augen und sie sehen sich verwundert an, sich fragend, ob sie denn wirklich alle das Zeug dem Champollion ${ }^{54}$ geglaubt hatten, was er ihnen weiß gemacht habe. Aber ist es nur möglich zu glauben daß es vor mir niemand eingefallen die ganze Sache einer vernünftigen Prüfung zu unterwerfen. In Eile. Bon soir.

[Randschrift:] Sie sehen wohl ein, daß ich jetzt den Hyacinth nicht eher zum auswärtigen Mitgliede vorschlagen kann als bis die Beschreibung von Tibet ganz fertig gedruckt ist, weil ich sonst als Poltron erscheinen würde. Dann aber soll es gewiß geschehen, denn ich habe eben so wenig gegen ihn als gegen Schmidt Rancune. Hyacinth hat viel Pfaffenstolz und Schmidt Herrnhuterischen kaufmännischen Eigendünkel.

A Son Excellence

monsieur le Baron

Paul Schilling de Canstadt

Au college des Affaires étrangeres

${ }^{53}$ KLAPROTH 1829.

${ }^{54}$ Jean-François Champollion (Figeac, 23 Dec. 1790 - 4 March 1832, Paris), linguist who managed to decipher a number of hieroglyphs and thus paved the way for a complete understanding of the old Egyptian scripts. Cf. Archives biographiques françaises. 
St. Petersburg

port payé

[marginal note] Pag 84 ligne 5 et pag 91 ligne 4 il faut lire «voyant qu'il n'existait aucun livre imprimé», etc.

9 [n.d.]

Guten Morgen,

Anbei das Tübetische Arzeneyenverzeichniß. Bemerken Sie daß der Verfasser nicht gut Chinesisch konnte, indem auf der Etiquette [---] gedruckt ist. Wie gefallen Ihnen [---] Georgische Buchstaben. [---] abgedruckt. Sein Sie so gütig [---] mir den Doy baslaba [---] das andere Heft der Hexa[--- $]^{55}$

Tout-à-Vous

$\mathrm{K} 1$.

A Monsieur

Monsieur le Baron de Schilling

62. Rue de Richelieu

Avec un étui rouge.

10 [n.d.]

Ich hoffe von Ihrer Großmuth, theuerster Herr Baron, daß Sie die Güte haben werden mir und Remusat ein Exemplar der Beschreibung von Tubet zu senden; denn auf Briefe und andere Communicationen von Ihnen können wir wohl nicht mehr rechnen.

$\mathrm{K} 1$

11 [n.d.]

Notes

In geschriebenem alten Catalog der Academie sind folgende Nummern als fehlend angemerkt.

$\mathrm{N}^{\circ} 23,24$ sind nur 3 Hefte statt 2 Bände. 32. 45 fehlt 1 Band. 51. 62.62*. 111. 130. 142. 143. 144. (Diese 3 Nummern sind die Karten.) $N^{\circ} 143$ und 144 befinden sich in Paris im Auswärtigen Depart. wo sie durch Segur ${ }^{56}$

${ }^{55}$ Text partly covered by the strip with Georgian letters.

${ }^{56}$ Probably the French diplomat Louis-Philippe de Ségur (Paris, 10 Sept. 1753 - 27 Aug. 1830), who acted as ambassador in St. Petersburg from 1783-1789. Archives biographiques françaises. 
hingekommen sind. 132 ist durch Wladikin ${ }^{57}$ an Kl. gekommen. 150 hat nur 2 Hefte statt ganz Tao. 177 soll 11 Hefte hat aber nur fünfe. 181 hat statt 6 Bände nur 3.

In der Bibliothek der Academie befindet sich Messerschmidts ${ }^{58}$ Tagebuch und andere Orientalia vom Ditto. ${ }^{59}$

Der alte Graf Stroganof hat eine Chinesische Sammlung von Münzen mit einem spanischen Catalog von [Manuel de] Agote ${ }^{60}$ spanischem Consul (?) in Canton.

\section{2 [1829]}

Seit Baron Merian's Tode habe ich keine Gelegenheit Paquete durch die Gesandtschaft nach St. Petersburg zu schicken. Seyn Sie daher so gefällig einem der jetzigen Secretaire derselben zu ersuchen meine Sendungen für Sie anzunehmen und auch abgehen zu lassen, damit nicht wieder solche Confusion entsteht wie mit dem Thung wen tchi.

Empfangen Sie meinen besten Dank für die drei Werke des Archimandriten, die ich vor einiger Zeit erhalten habe. Sollte es möglich seyn so bitte ich mich auch mit der Beschreibung von Peking ${ }^{61}$ nebst Plan zu bedenken, aber sowohl Russisch als Französisch, denn man kann sich nie auf Übersetzungen verlassen.

Wenn Sie recht freundschaftlich seyn wollten, so schicken Sie mir auf einige Zeit das 金遼元國三史語解.

Schmidt Mongolische Geschichte ist hier noch nicht angelangt. Wir warten mit Verlangen darauf.

Paris d. 18 Oct 1829

Sie werden wahrscheinlich schon das Siamische Vocabulair haben copiren lassen. Seyn Sie so gütig mir mein calquirtes Exemplar zurück zu senden.

\footnotetext{
${ }^{57}$ Anton Vladykin (1761-1811), Sinologist and interpreter. Cf. WALRAVENS 1982.

${ }^{58}$ Daniel Gottlieb Messerschmidt, (Danzig, 13 April 1685 - 25 March 1735, St. Petersburg), physician and explorer; he undertook a research trip through Siberia for seven years; unfortunately part of his rich collections were lost when he suffered ship-wreck in the Baltic Sea. His travel diaries were only published in Berlin (MESSERSCHMIDT 1962-1977), with the commentaries considerably abridged). Cf. JAHN 1885.

${ }^{59}$ «The said, the mentioned».

${ }^{60}$ Manuel de Agote - no further details found.

${ }^{61}$ Cf. EYRIÈs, KLAPROTH 1829.
} 
13 [n.d.]

Bitten für mich

Was von Sibirischen, Caucasischen Georgischen Charten seit 1822 herausgekommen ist und noch heraus kömmt.

1. Broniewski Kaukasus ${ }^{62}$

1. Timkowski, Womöglich 2 Exempl. von der Charte

Die Georgischen Costüme und Kaukasischen die in S. Petersburg lithographirt sind.

Orlowski ${ }^{63}$ von mir zu grüßen und zu bitten mir seine Persische Lithographien zu schenken.

Reichel bei der Bank bestens zu grüßen

Zepplin ebenfalls und ihn zur auswärtigen Correspondenz über geographisch-historische Gegenstände anzumahnen.

Der Academische Arzt, der 1809 erblichen ist, hatte mir einen Chinesischen Original Atlas versprochen. Diesem nachzustellen.

Description de Peking auf einen Monat nach Paris.

14 [n.d.]

Curiosa in der Bibliothek der Academie in St. Petersburg

Historico Politica

14. Kurze Beschreibung der Reise von St. Petersbg. nach Peking

132. Messerschmidts Sibiria perlustrata

${ }^{62}$ BRONEVSKII (1823). - State councillor Semen Mikhailovich Bronevskii (1763 - Dec. 27, 1830) was head of the Chancery of the Commander-in-chief of the Caucasus in Tiflis, Prince P.D. Tsitsianov. Cf. ANON 1908.

${ }^{63}$ Aleksandr Osipovich Orlovskii (1777-1832): 41 drawing for book: «Drouville, Voyage en Perse, pendant les années 1812 et $1813 \ldots$ St. Petersbourg. Imprimé chez Pluchart, a ses frais. F Paris chez Firmin Didot 1819». Два тома $4^{\circ}$ и атлас. В первом издании сего атласа 1819 г. он озаглавлен: Atlas pour servir au voyage en Perse, Pendant les années 1812 et 1813, Par Gaspard Drouville. - La plus grande partie des dessins ont été Lithographies par M.M.A. Orlowsky, Swébach, et autres artistes. В этом Атласе имеются ниже поименованные 59 рисунков и карта Персии. В моем собрании находится третье издание этого Атласа со следующим заголовком: Atlas ou Collection de 43 Costumes [Два из них (№№ 18 и 27) уже были изданы Орловским прежде и описаны выше под №№ 43 и 44.] Persans militaires et civils, Dessinés par A. Orlowsky, pour orner le voyage de Perse, fait pendant les années 1812 et 1813. Par Gaspar Drouville, Colonel de Cavallerie au service de S.M. l'Empereur de toutes les Russies. Troisième tirage... St.-Pbg... Pluchart... 1823. (According to Rovinskii. See

https://dic.academic.ru/dic.nsf/enc_biography/96278/\%D0\%9E $\%$ D1\%80\%D0\%BB $\% \mathrm{D} 0 \%$ BE\%D0\%B2\%D1\%81\%D0\%BA\%D0\%B8\%D0\%B9). 
133. Varia Messerschmidtiana ad geographiam et historiam Naturae spectantia. 3 vol.

206. Collectanea Messerschmidtii ad linguas Sibiriae spectantia.

Lassen Sie davon eine Copey für mich machen.

Im Archiv der Academie Resanows ${ }^{64}$ Russisch Japanische Grammatik nebst Wörterbuch

15 [n.d.]

Mir fehlt das 7e. Blatt des 163. kiven [卷] des Thai tsing y thung tschi ${ }^{65}$. Nach dem academischen Exemplare.

Provinz Kan su, district 府州甘

Das vorhergehende 6e. Blatt endigt mit 自。渠水.

Das folgende 8e. Blatt fängt an 末梁後

Wie heißen die boules chinoises ${ }^{66}$ und Godmichés ${ }^{67}$

Wie hängt es mit dem Brennen der Frauenzimmer zusammen.

16 [n.d.]

Supplement zum Mandshuischen Wörterbuche

Könnten Sie mir nicht mit demselben die Beschreibung von Peking senden.

$17[1830]$

Ich hoffe, daß Sie diese Zeilen nebst Beilagen, in bester Gesundheit, an der Chinesischen Gränze treffen werden. Duplicate einiger Broschüren erhalten Sie durch A. Turgeneff, der in acht Tagen von hier nach Moskau abreist. Empfehlen Sie mich dem P. Hyacinth und bitten ihn in meinem Namen, nicht zu glauben, daß Feindschaft mich anreize gegen ihn zu schreiben, aber den Unsinn der Khian lung-schen Commission konnte ich nicht unnotifizirt der Europäischen Welt übergeben lassen. Vergessen Sie nicht

Ihren ergebensten

Paris 15 Sept. 1830

JHKlaproth

${ }^{64}$ Nikolai Petrovich Rezanov (1767-1807), Russian diplomat, participant of the Krusenstern expedition, went to Nagasaki in 1804 but was not accepted by the Japanese government. He retaliated by having some villages on Sakhalin Island pillaged in 1806. Cf. WALS 1941.

${ }^{65}$ 大清一統志.

${ }^{66}$ To be inserted in the vagina to increase lustful sensations.

${ }^{67}$ Dildoes. 
18 [1831]

Paris 1 mars 1831

5 Rue d'Amboise

Je ne sais pas, mon cher Baron, avec quoi nous autres pauvres Parisiens, nous avons merite Votre animadversion, mais nous devons effectivement craindre d'avoir entièrement perdu Votre bienveillance, puisque depuis plusieurs années Vous ne donnez aucun signe de vie, et il paraît que vous Vous étez expressement retiré à la frontière du Céleste empire, pour trouver une raison plausible de cet oubli.

Malgré Votre attitude boudeuse nous pensons souvens à Vous, et je prens la liberté de me rapeller à Votre souvenir par l'envoi ci-joint, que je Vous prie avec bonté quoiqu'il ne sera peut-être tout-à-fait agréable à Votre compagnon de Voyage. Soyez pourtant convaincu que mon but en refaisant son livre a été de le facher. Au contraire Vous savez que j'ai été toujours trèsporté pour lui. Mais la description du Tubet devait paraître en Europe dans une langue généralement intelligible, et il était alors impossible de la publier aussi defectueuse, quelle l'etait dans la traduction russe.

Pour consoler le P. Hyacinthe je le proposerai Lundi prochain comme Membre externe de la Société Asiatique, et je ne doute pas que cette compagnie savante ne s'empresse à se l'adjoindre à ce titre. Dans un mois je pourrais donc avoir le plaisir de lui envoyer la notification de sa nomination, que je m'empresserai de faire mettre dans le Moniteur et dans d'autres Journaux.

J'ai beaucoup de cahiers du Journal Asiatique pour Vous, mais je ne sais pas comment Vous les faire parvenir, et je crains si je les envoye d'ici par un Courrier de l'Ambassade ils ne restent aux Affaires étrangères à St. Petersbourg.

Je reviens toujour à mon ancienne démande relative à un 鑑文清 avec le Mongol et le Tubetain. ${ }^{68}$ Veuillez me faire le plaisir de m'en procurer un s'il est possible, et agréez d'avance les remerciments et les civilités de

Votre très humble et très obeissant Serviteur

JHKlaproth

${ }^{68}$ Duin hacin-i hergen kamciha Manju gisun-i buleku bithe. Yuzhi siti Qing wenjian 御製 四體清文鑒. 36 fasc. or: Duin hacin-i hergen kamciha buleku bithe. Siti hebi wenjian 四體合 壁文鑒 40 juan. Cf. WALRAVENS 2014, no. 255, 288. 
Liebe Hanny,

Wenn ich Dich ansehe, so sehe ich daß du mich liebst und möchte vor Freude weinen. ${ }^{69}$

20

The following table of contents of a description of the Caucasus and Georgia does not in any way match either the Voyage au mont Caucase et en Géorgie (1823) nor the Tableau historique, géographique, ethnographique et politique du Caucase et des provinces limitrophes entre la Russie et la Perse (1827). Thus it seems to be an outline for a description of the Caucasus that was not realized.

Ie. Partie

Introduction - Notions géographiques générales. Notions préliminaires du Caucase.

Chap. I. - Etendue, limites, denominations, population primitive, progrès geographiques. Epoques historiques:

Epoque 1 - Période grecque

Epoque 2 - Période romaine

Epoque 3 - Période byzantine ou greco-persane

Epoque 4 - Période turco-persane

Epoque 5 - Période russe

Religion - Langue - Mœurs - Manière de vivre - Gouvernement Difference des conditions - Politique - Commerce - Population - Revenue.

Chap. II - Coup-d'œil sur l'etat physique du Caucase - Montagnes et rivières.

a. Position et analyse des montagnes prises dans toutes leurs directions; d'après Guldenstædt. Tchorokhi.

b. Rivières - Terek - Kouma - Kouban - Rion - Engouri \& Khopi -

Chap. III - Notions sur le commerce du Caucase.

a. Commerce de terre ferme et de la mer Caspienne

b. Commerce ancien et moderne du Kour et du Phahe

\footnotetext{
${ }^{69}$ Whether this strip of paper really belongs to this file is doubtful.
} 
Chap. IV - Nomenclature de quelques animaux du Caucase et de la Géorgie, d'après le système de Linné.

Divisions principales du Caucase

- Contrée occidentale, ou rivage du nord-est de la mer Noire. - Du trafic des esclaves.

2. Section - L'Abkhazie ou Abaza - Petite Abazie - L'Abkhazie du N.O. - L'Abkhazie du S.O. - Territoire de Sokhou kalah - Notions sur le commerce de cette côte.

\section{Partie}

Region septentrionale du Caucase.

Chap. I. Coup d'œil général - Etendue, limites - Fragments sur l'etat physique de la region septentrionale du Caucase, prises en grande partie dans les observations de Guldenstædt et de Poltar.- Mont Elbrouz - Monts Bech$\tan$ - Production - Eaux minerales.

Chap. II. Tcherkesses - Coup d'œil général - Limites - Monuments remarquables dans la contrée des Tcherkesses - Division de leur pays Tcherkesses transkoubaniens - Kabardie - Origine, histoire - Grande Kabardie - Petite Kabardie - territoire sans nom et contrée de Baragoune Etat civil et politique des Tcherkesses, et principalement des Kabardiens Religion - Langue - Formes exterieures - Costume - Manière de batir Education - Loix ou gouvernement - Coutumes qui tiennent lieu de loix Manière de faire la guerre - Mœurs - Mariage - Hospitalité - Mediation des femmes - rixes et Duels - Economie rurale - Agriculture - Haras - Education des bestiaux - Aliments - Revenues - Sciences - Métiers - Commerce - Amusements - Maladies - Funerailles.

Chap. III Kistes - Etendue et limites - Rivieres - Denominations Origine, histoire - Langue.

- Kistes - Ingouches - Karaboulaks - Tchetchentses.

Chap. IV Koumik's - Etendue, limites - Rivières, position et proprieté du sol - Oriine, notions historiques - Division du territoire - Observations générales -

Chap. V - Tribus Nogay, etablies vers la contrée septentrionale du Caucase - Nogay nomades en deçu du Terek et du Kouban - Nogay etablies chez les montagnards au delà du Terek, de la Mulka et du Kouban - Nogay établis dans les montagnes du Caucase au delà du Terek et du Kouban, dans le courant du $18 \mathrm{e}$ ou vers la fin du $17 \mathrm{e}$ siècle. 
Explication des signes appelés Tarzei, dont on marque les chevaux dans les huras.

Partie Orientale du Caucase

Chap. I - Coup d'œil général - Limites, etendue - Division générale Proprieté du sol - Production - Economie rurale, agriculture - Animaux domestiques.

Chap. II Le Daghestân - Denomination - Limites - Domaine du Chamkhal de Tarkou - Djangotei - Langue - Domaine de l'Ouzmei des Kara Kaidak - Recherches sur la ville de Koubitchi et sur l'origine européenne de ses habitans - Khanat de Derbend - Tabasseran -

Chap. III - Le Chirwan - Coup d'œil général - Pleine entre le Samour et l'Ata tchou et la Territoire sterile entre l'Ata tchou et la vallée en deçu du Kour - Vallée sur la gauche du Kour -

\section{1}

Paris 8 Aout 1833

5 Rue d'Amboise

Monsieur

Je m'empresse de Vous offrir mes remerciments pour le beau cadeau que Vous avez eu la bonté de me faire, et pour la bienveillance que Vous me montrez dans Votre lettre du 12 Juillet.

Tous les Orientalistes, et principalement ceux qui s'occupent d'étudier les antiquités et l'ancien idiome de l'Inde, vous avaient dejà la plus grande obligation pour la publication de la première édition de Vôtre excellent Dictionnaire sanscrit; leur gratitude doit doubler quand ils verront la service si considérablement augmentée et perfectionnée. Revenu dans Votre patrie dans le climat est plus proprice aux travaux scientifiques, que celui de l'Inde, nous espérons tous que Vous nous ferez participer des riches trésors que Vous avez rapportes des bords du Gange, et que le Ciel Vous accordera la santé et le bien-être necessaire a d'autres travaux, qui ils ne peuvent ajouter à Votre gloire, contribueront toujours à rendre l'Inde et sa littérature plus connue en Europe, et exciteront un plus grand nombre de personnes à l'étude de sanscrit, cette langue si merveilleuse à laquelle aucune autre du monde se peut comparer.

Je Vous remercie aussi pour l'envoi du XVIIe volume des Asiatic Researches, que j'ai trouvé dans le même paquet que le Dictionnaire, et que je 
dois par consequent egalement à Votre bonté. Je saisis Votre offre de m'être utile dans mes relations avec Calcutta, et je prendrai dans quelque temps la liberté de Vous envoyer un petit mémoire pour la Société Asiatique de cette ville, dans lequel je me propose d'exposer, ce que je pense qu'il faudroit faire pour resoudre la question relative au Cours inférieur du Tsang-bo du Tubet. Je suis fache que je n'ai pas donné cet exposé il y a long-temps, car si je l'avais fait Mr. Wilcox ${ }^{70}$, aurait pu resoudre la question, lors de son dernier séjour dans l'Assam.

Je n'ai eu aucune nouvelle du paquet de Calcutta qui a été en effet ainsi adressé à $\mathrm{Mr}^{\mathrm{s}}$. Eyriès frères au Havre, mais qui n'y est jamais arrivé. Neanmois je Vous remercie toujour pour le soin que Vous avez bien voulu donner à cette petite commission et j'ai l'honneur d'être

Votre très-devoué

JHKlaproth

Copy of a letter to Horace Hayman Wilson ${ }^{71}$ in the Fond Klaproth of the Academy Archive. Cf. KLAPROTH 2002, 175.

\section{2}

Nicht treffender hätte der gelehrte Verfasser dieser Critik die Arbeiten des verstorbenen Champollion über die Hieroglyphen characterisiren können, als durch das so glücklich gewählte Motto des Plinius: Nitor verius quam splendor, «Mehr Schimmer als leuchtender Glanz». In der That sind wir nur durch Champollions Entdeckungen aus der finsteren Nacht, welche die Litteratur der alten Ägypter bedeckte, in eine, bis jetzt noch sehr spärliche, Dämmerung getreten, wie diese ist, wenn sich am frühsten Morgen sich die Umrisse ferner Gebirge noch kaum von dem Helldunkel des Horizontes trennen. Vieles, fast noch alles bleibt zu thun übrig, ehe man dahin kommen wird etwas heller zu sehen. Die ersten Versuche Champollions, die er in seinem Briefe an Herrn Dacier 1822 bekannt machte, sind unstreitig der gediegenste Theil seiner Arbeiten über die Hieroglyphen. Es ging ihm aber wie dem eifrigen Bergmann, der, wenn er irgendwo eine kärgliche Goldader entdeckt hat, trotz seines Eifers die fernere Spur derselben verliert, und nun mit gieriger Hand und mit fruchtloser Mühe im tauben Gesteine fort arbeitet.

\footnotetext{
${ }^{70}$ WILCOX 1832.

${ }^{71}$ H.H. Wilson (1786-1860), britischer Arzt und Indologe. Cf. B. 1890.
} 
Die Entdeckung des phonetischen Alphabets, die Champollion in den Stand setzte Griechische, Römische und auch einige Ägyptische Eigennahmen zu lesen, mußte allgemein Beifall finden, denn sie war in allen ihren Theilen erwiesen. Dieses Alphabet setzte jeden neugierigen Leser in den Stand, auf dem vom Entdecker vorgezeichneten Wege fort zu gehen, und es auf den Monumenten selbst zur Entzifferung solcher Eigennahmen mit Glück anzuwenden. Ein litterarischer Zeitvertreib, der gewisser maßen das damals schon aus der Mode kommende Casse-tête chinois ${ }^{72}$ ersetzte, nur mit dem Unterschiede, daß bei jenem die Stücke nicht immer so gut an einander paßten als bei diesem. Die Gewissenhaftigkeit und der regelmäßige Gang der Demonstration welche in dem Briefe an H. Dacier ${ }^{73}$ nicht zu verkennen waren, konnten nicht anders als ein günstiges Vorurtheil für diesen Verfasser erwecken, und man durfte sich mit der Hoffnung zu schmeicheln, daß der, welcher seine Laufbahn so rechtlich angefangen hatte, auch auf derselben eben so rechtlich und redlich fortwandeln werde. Äußere Umstände, die Beschränktheit der Menge und der Neid der französischen Gelehrten zwangen ihn aber bald auf Abwege zu gerathen. Seit mehr als zehn Jahren hatte Champollion mit Eifer über die Hieroglyphen gearbeitet, ohne jedoch zu einem Resultate zu gelangen; vielmehr hatte er es versucht, bei seiner keineswegs glücklichen Lage, von den gelehrten Instituten Frankreichs oder von der Regierung Unterstützung zu erlangen. Endlich leitet ihm des Engländers Young Idee, tonangebende Zeichen in der ägyptischen Schrift zu suchen, auf die Entdeckung des phonetischen Alphabets, er macht sie bekannt, beweißt ihre Richtigkeit, wird allgemein bewundert, aber man thut nichts für ihn. Wo er um Unterstützung anfrägt, erhält er zur Antwort: «Sie lesen ja nur Eigennahmen; erst wenn Sie dahin gekommen seyn werden, Texte zu entziffern, können Sie auf academische Ehrenstellen und pecuniäre Belohnungen Anspruch machen». Natürlich mußte da dem Manne der Muth sinken.

Hätte er seine Entdeckung vor achtzig oder neunzig Jahren machen können, so würde er mit Belohnungen überhäuft worden seyn. Das einzige was er jetzt von der Französischen Regierung erhalten konnte, war das Versprechen, daß, wenn er ein Werk über die Entzifferung der Hieroglyphen schriebe, man es in der Königlichen Druckerei unentgeldlich drucken, und dann sehen wolle was für ihn zu thun sey. Geschäftige Freunde riethen ihm, das

\footnotetext{
72 Tangram, 七巧.

${ }^{73}$ Bon-Joseph Dacier (1742-1833), historian and philologist, member of the Académie française, editor of the Journal des savants. Here reference is made to CHAMPOLLION 1822.
} 
Eisen zu schmieden weil es an der Zeit sey und einen Précis du Système hieroglyphique des anciens Egyptiens heraus zu geben. Champollion ward nun bei Hofe und den höheren Zirkeln wie eine Art Zauberkünstler oder Faiseur de tours de passe-passe vorgestellt; Herrn und Damen drängten sich um ihn und baten um die Entzifferung ägyptischer Pasten die in ihren Busennadeln prangten. In Gegenwart des diplomatischen Corps und der besten Gesellschaft und ihre Pässe für die Ewigkeit dem neuen Hierophanten überreicht, den man zwang sie aus dem Stegereif abzulesen und zu erklären. Wenn nun bei diesem abgeschmackten Treiben dem armen Champollion auch nicht das Verständnis der Ägyptischen Schrift weiter eröffnet wurde, so ward ihm doch das Decipiatur mundus klar, und er gewiß wider seinen Willen zum Charlatan gestempelt. Stets gezwungen das zu erklären, was er nicht verstand, scheint es daß er bald anfing selbst an seine Erklärungen zu glauben und ein Opfer eigener Täuschung ward.

Indessen ging der Gang des Druckes des Précis langsam fort und ward erst 1824 vollendet. Dieses Werk ist ein sonderbares Gemisch von wirklichen Entdeckungen und unhaltbaren Behauptungen. $\mathrm{Zu}$ einem Précis $d u$ système hieroglyphique fehlten noch die ersten Elemente, und doch zwang eine eiserne Nothwendigkeit den Verfasser ein solches System in die Welt zu schicken, wenn er nicht wollte, daß alle seine Bemühungen um das Studium der Hieroglyphen für ihn selbst unfruchtbar würden. Er war genöthigt in diesem Buche Grundsätze aufzustellen, von welchen der Gang seiner Untersuchungen in demselben Werke ihn häufig abzugehen nöthigte. Aus dieser Ursache ist ein beständiges Schwanken in den Behauptungen des Verfassers nicht zu verkennen das er selbst in Hinsicht des phonetischen Alphabets nicht hat vermeiden können. So ist bei ihm das Auge ohne Brauen bald ein s, bald ein Vocal; und bald bezeichnet es das Glied selbst welches es vorstellt. Die letztere Annahme ist aber dem von H. Champollion aufgestellten Grundsatze schnurstracks entgegen «daß die einmal als phonetisch anerkannten Zeichen ihren phonetischen Valor in allen hieroglyphischen Texten beibehalten». - Ein Zeichen das H. Champollion bald ein Blatt bald eine Feder nennt, ist in seinem Alphabet ein s; anderweitig bezeichnet es die Göttin Sate oder Juno und später Toné oder Themis. - Eine fliegende Ente oder Gans drückt einmal den Vocal e oder ie aus, dann wieder in vielen Texten ein p. - Eine zirkelfömige Figur wird zuerst für ein $r$ gegeben, dann für ch, für u oder ooh, und bezeichnet endlich die Sonne. - Ein Arm dessen Hand einen Hacken hält ist hier ein Vocal, dort bedeutet er leiten, Leiter. - Ein Widder bezeichnet den Buchstaben b, dann wieder Leben oder Geist. - Eine 
Räucherbüchse ist ein $b$, bedeutet aber auch Anbetung, Verehrung, - Die Schwalbe bezeichnet bald den Consonanten dsh, bald den Vocal ô. Eine Menge ähnlicher Abnormitäten und Abweichungen von der festgesetzten Regel, beweisen wie wenig man auf die Angaben des H. Champollion fussen kann.

Was die symbolischen und ideographischen Hieroglyphen betrifft so eröffnet sich bei diesen noch ein viel weiteres Feld gewagte und unstatthafte Behauptungen. Um hier das Ansehen zu haben auf einer festen Grundlage zu arbeiten, hat der verstorbene Champollion sich genöthigt gesehen eine neue ägyptische Mythologie aufzustellen, die mit der, welche wir fragmentarisch aus den Schriften der Alten ziehen können, wenig oder gar nichts gemein hat. Die Materialien zu diesem mythologischen Systeme behauptet Champollion in den graphischen Denkmälern der Ägypter gefunden [zu] haben, und er benutzt nun jene Systeme um diese zu erklären, also das unbekannte durch das Unbekannte. Der Raum erlaubt es nur nicht in die vielen Einzelheiten einzugehen, die H. Klaproth in seiner Kritik auseinandersetzt. Sie lassen sich auch nicht ohne Hülfe der hieroglyphischen Zeichen dem Leser genügend darstellen. Es sei mir hier nur erlaubt die oft gemachte Bemerkung zu wiederholen, daß wenn H. Champollion wirklich im Stande gewesen wäre, die Hieroglyphen Schrift zu übersetzen und zu erklären, der wahre Probierstein seiner Kunst die Inschrift von Rosette seyn mußte, weil er die einzige ist, von der wir die griechische gleichzeitige Übersetzung besitzen. Aber diese Klippe hat er stets weislich vermieden, um nicht an derselben einen gänzlichen Schiffbruch zu leiden. In der That, sehen wir auch durch die von H. Klaproth gemachte Zusammenstellung der hieroglyphischen Zeichen einer Zeile der erwähnten Inschrift und der wenigen ungewissen wo man in über einem Theil dieser Zeilen in den Schriften Champollions findet, daß es ihm unmöglich gewesen den Inhalt des Monuments mit den ihm zu Gebote stehenden Hilfsmitteln nur einigermaßen zu deuten.

Das Bewußtsein seiner Schwäche hat Champollion stets abgehalten auf gegründete Einwürfe gegen seine Hypothesen zu antworten; er hat nur diejenigen seiner Gegner öffentlich zu bekämpfen gesucht, die ihn mit unhaltbaren Gründen angefochten haben, oder deren Unbehülflichkeit er genugsam kannte, um nichts von ihnen befürchten zu dürfen. Was diejenigen Personen betrifft, die auf die Gewissenhaftigkeit seiner Arbeiten, auf die Richtigkeit seiner Angaben sich mit Untersuchungen über die Hieroglyphenschrift beschäftigt haben, so begreifen wir wohl daß es ihnen jetzt schwer fallen muß [auf] die Illusion zurück zu kommen, in der sie eine Zeitlang gelebt haben. Wie glauben daher, daß weder sie, noch entschiedene Gegner Champollions, 
werden als Schiedsrichter zwischen dem verstorbenen und den Verfassern der Kritik seiner Arbeiten auftreten werden; weil es natürlich beiden an Unpartheilichkeit fehlen muß. Es steht also zu hoffen, daß es anderen überlassen werde, das Wort in dieser Angelegenheit zu führen, die nicht vor ihr Forum gehört. ${ }^{74}$

\section{References}

Амiot, Jean Joseph 1770: Éloge de la ville de Moukden et de ses environs. Poème composé par Kien-Long, Empereur de la Chine \& de la Tartarie, actuellement régnant. Accompagné de notes curieuses sur la géographie, sur l'histoire naturelle de la Tartarie Orientale, \& sur les anciens usages des Chinois; composées par les éditeurs chinois $\&$ tartares. On y a joint une pièce de vers sur le thé, composé par le même Empereur. Traduit en françois par le P. Amiot, Missionaire a Péking; et publié par M. Deguignes. Paris: Tilliard. XXXVIII, $381 \mathrm{pp}$.

ANON 1844: "Mr. William Huttmann”. In: Asiatic Journal 4 (Nov.), 104-105.

ANON (n.d.) 1903: “Krug, Johann Philipp”. In: Russkii biograficheskii slovar 9, 451-454.

ANON 1908: "Bronevskii Semen Mikhailovich". In: Russkii biograficheskii slovar 3, 362-363.

B., C. (1890): "Wilson, Horace Hayman". In: Dictionary of National Biography 21, 568-570.

Bronevski, Semen 1823: Noveishie geograficheskie i istoricheskie izvestiia o Kavkaze. 2 T. Moscow.

BROSSET, Marie-Félicité 1841: "Rapport à l'Académie Impériale des sciences, sur la Bibliothèque chinoise du Musée asiatique". In: Bulletin scientifique 8, col. 225-240.

Burnouf, Eugènea and LASSEn, Christian 1826: Essai sur le Pali, ou Langue sacrée de la presqu'ole au dela du Gange; avec six planches lithographiées. Paris: Dondey-Dupré. $222 \mathrm{pp}$.

Champollion, Jean-François 1822: Lettre à M. Dacier relative à l'alphabet des hiéroglyphes phonétiques. Paris: Firmin-Didot. 44 pp.

DiEDERICHS, Heinrich 1883: "Lieven, Karl von". In: Allgemeine Deutsche Biographie 18, 639-641.

Eyriès, J.B. and KlAPROTH, J. 1829: "Rapport sur le plan de Péking, publié à St. Pétersbourg en 1829”. In: Nouveau Journal asiatique 4, 356-374 (J.B. Eyriès, J. Klaproth, rapporteur).

Fraenn, Christian M. 1825: Abu'l-Ghāzī Bahādur Khān, Chiwa, Chan, 1603-1663: Historia Mongolorum et Tatarorum. Ed. by Christian Martin Fraehn. Casani: Univ. IX. 209 pp.

His, Eduard 1941: Basler Gelehrte des 19. Jahrhunderts. Basel: Schwabe. 432 pp.

JAHN, Ilse 1885: "Messerschmidt, Daniel Gottlieb". In: Allgemeine Deutsche Biographie 21, 494-497.

[KLAPROTH 1815]: Lettres sur la littérature Mandchou, traduites du russe de M. Afanasii Larionowitch Leontiew. Paris: de l'imprimerie de Fain. III. 75 pp.

[KLAPROTH, Julius 1815]: Grande exécution d'automne. No. II. Langlès.

KlAPROTH, Julius 1819: Supplément au dictionnaire chinois-latin du P. Basile de Glemona (imprimé en 1813 par les soins de M. de Guignes); Dictionnaire chinois, françois et latin. Paris: Imprimerie royale. X, $168 \mathrm{pp}$. large in $4^{\circ}$.

${ }^{74}$ This is a review of KLAPROTH 1832. 
Klaproth, Julius 1824: Beleuchtung und Widerlegung der Forschungen über die Geschichte der mittelasiatischen Völker des Herrn J.-J. Schmidt, in St. Petersburg. Paris: DondeyDupré. $115 \mathrm{pp}$.

KLAPROTH, Julius 1825/6: Magasin asiatique ou revue géographique et historique de l'Asie centrale et septentrionale. T. 1. Paris: Libr. Orientale de Dondey-Dupré.

KLAPROTH, Julius 1826: "Description du Si Dzang ou Tubet, d'après la grande géographie impériale de la Chine et le Dictionnaire de l'Asie centrale, publié à Peking, en 1775". In: Magasin asiatique... T. 2, 209-307.

Klaproth, Julius 1826b: Tableaux historiques de l'Asie, depuis la monarchie de Cyrus jusq'a nos jours; précedés de recherches historiques et ethnographiques sur cette partie du monde. Atlas. [Dedicated to] Guillaume et Alexandre de Humboldt. Paris, Londres, Stuttgard. 27 fol.

KLAPROTH, Julius 1827a: Lettre sur la découverte des hiéroglyphes acrologiques, adressée à M. le chevalier de Goulianoff, membre de l'Académie russe. Paris: J.S. Merlin. 43 pp.

KLAPROTH, Julius 1827b: Seconde lettre sur les hiéroglyphes, adressée à M. de $S^{* * * * *}$. Paris: J.S. Merlin. 45 pp.

KLAPROTH, Julius 1828a: Mémoires relatifs à l'Asie, contenant des recherches historiques, géographiques et philologiques sur les peuples de l'Orient; par M.J. Klaproth, membre du Conseil de la Société asiatique de Paris. Tome troisième. Paris: Dondey-Dupré. 517 pp.

KLAPROTH, Julius 1828b: Chrestomathie mandchou ou Recueil de textes mandchou, destiné aux personnes qui veulent s'occuper de l'étude de cette langue, par J. Klaproth. (Paris) Imprimerie royale. XII, $275 \mathrm{pp}$.

KLAPROTH, Julius 1829: "Observations critiques sur l'alphabet hieroglyphique decouvert par M. Champollion le jeune, et sur le progrès fait jusqu'a ce jour dans l'art de dechiffrer les anciennes écritures égyptiennes". Introduction to: Collection d'antiquités égyptiennes recueillies par M. le chevalier de Palin. Paris.

KlAProth, Julius 1832: Examen critique des travaux de feu M. Champollion sur les hiéroglyphes. Paris: Librairie orientale de Dondey-Dupré, VIII, 175 pp.

KLENZ, Heinrich 1904: “Christian Martin Joachim Frähn”. In: $A D B$ 48, 674-676.

LANDRESSE, Clerc de 1826: Supplément à la grammaire japonaise du P. Rodriguez, ou Remarques additionnelles sur quelques points du système grammatical des Japonais, tirées de la grammaire composée en espagnol par le P. Oyanguren, et traduites par M.C. Landresse. Paris: Dondey-Dupré, $31 \mathrm{pp}$.

LOUVET, L. 1856: "Eyriès, Jean-Baptiste Benoît". In: Hoefer: Nouvelle biographie générale $16,870-873$.

MeSSERSChMidT, Daniel Gottlob 1962-1977: Forschungsreise durch Sibirien 1720-1727. Berlin: Akademie Verlag.

MORRISON, Robert 1815-1823: A dictionary of the Chinese language, in three parts: part the first, containing Chinese and English, arranged according to the radicals, part the second, Chinese and English arranged alphabetical, and part the third, English and Chinese, by the Rev. Rob. Morrison. Macao: Printed at the Honourable East India Company Press.

MunKuEv, C.N. (n.d.): “Timkovskii Egor Fedorovich”. Chronos (http://www.hrono.ru/biograf/ bio_t/timkovskiegfe.php).

RÉMUSAT, Jean-Pierre A. 1816: Le livre des récompenses et des peines, traduit du chinois, avec des notes et des éclaircissemens; par M. Abel Rémusat, Docteur en médecine de la Faculté de Paris, de l'Académie royale des inscriptions et belles-lettres, Lecteur royal et professeur de chinois et de Tartare-mandchou au Collège royal de France. A Paris, chez Antoine-Augustin Renouard, M.DCCC. XVI. 79 pp. 
RÉmUSAT, Jean-Pierre A. 1819: "Supplément au Dictionnaire chinois-latin du P. Basile de Glemona (imprimé, en 1813, par les soins de M. de Guignes), publié par Jules Klaproth. A Paris, de l'imprimerie royale 1819". In: Journal des savants, 694-698, 736-748.

RÉMUSAT, Jean-Pierre A. 1826: Iu-kiao-li, ou Les deux cousines; roman chinois, traduit par M. Abel-Rémusat; précédé d'une préface où se trouve un parallèle des romans de la Chine et de ceux de l'Europe. Tome 1-4. Paris: Moutardier. 12 1: 256 pp.; 2: 172 pp.; 3: 196 pp.; 4: $239 \mathrm{pp}$.

RÉMUSAT, Jean-Pierre A. 1827: "Notice sur l'encyclopédie japonais et sur quelques ouvrages du même genre". Notices et extraits des manuscrits de la Bibliothèque du roi et autres bibliothèques $11,123-310$.

SALMON, Georges 1905, 1923: Silvestre de Sacy (1758-1838). Le Caire: Institut français. CXVI, 264; XL, 277 pp. (Bibliothèque des arabisants français 1).

SKACHKOv K.A. 1875: "Eshche o pokoinom Timkovskom”. Moskovskie vedomosti, March 14, no. 66.

TimkovSKII, Egor Fedorovich 1824: Puteshestvie v Kitai chrez Mongoliiu v 1820 i 1821 gg. Saint-Petersburg: Ministerstvo Vnutrennikh Del, 3 vols.

TIMKOVSKII, Egor Fedorovich 1827: Voyage a Peking, a travers la Mongolie, en 1820 et 1821. Ouvrage accompagné d'un atlas qui contient toutes les planches de l'original, et plusieurs autres inédites. Paris: Dondey-Dupré.

WALRAVENS, Hartmut 1982: "Anton Vladykin. Eine Biobibliographie des russischen Mandjuristen und Sinologen". Uralaltaische Jahrbücher NF 2, 291-298.

WALRAVENS, Hartmut 1984 (ed.): Onorato Martucci: Schriften über China. Mit einer biobibliographischen Skizze und einem Faksimile eines Auktionskataloges. Hamburg: C. Bell, 176 S. $4^{\circ}$ (Han-pao tung-Ya shu-chi mu-lu 25).

WaLraVEns, Hartmut 1988: Iakinf Bičurin, russischer Mönch und Sinologe. Eine Biobibliographie. Berlin: Bell. 70 p. (Han-pao tung-Ya shu-chi mu-lu 34).

WALRAVENS, Hartmut 1992a: “Aleksej Leont'ev und sein Werk. Eine Bibliographie”. Aetas Manjurica 3, 404-431.

WALRAVENS, Hartmut 1992b: Antonio Montucci (1762-1829), Lektor der italienischen Sprache, Jurist und gelehrter Sinologe. - Joseph Hager (1757-1819), Orientalist und Chinakundiger. Zwei Biobibliographien. Berlin: Bell. 106 p. $4^{\circ}$ (Han-pao tung-Ya shu-chi mu-lu 42).

WALRAVENS, Hartmut 1999: Zur Geschichte der Ostasienwissenschaften in Europa. Abel Rémusat (1788-1832) und das Umfeld Julius Klaproths (1783-1835). Wiesbaden: Harrassowitz. 183 pp. (Orientalistik Bibliographien und Dokumentationen 5).

WALRAVENS, Hartmut 2002a: Isaak Jakob Schmidt (1779-1847); Schriftenverzeichnis. Berlin. $71 \mathrm{pp}$.

WALRAVENS, Hartmut 2002b: Julius Klaproth: Briefwechsel mit Gelehrten. Wiesbaden: Harrassowitz.

WALRAVENS, Hartmut 2004: "Konnte der Drucker und Verleger Karl Tauchnitz Tibetisch?" Aus dem Antiquariat 2, 83-91.

Walravens, Hartmut 2014: Mandschurische Handschriften und Drucke im Bestand der Staatsbibliothek zu Berlin. Stuttgart: Steiner.

WALs, Karl 1841: "Rezanov”. In: Japan-Handbuch. Berlin: Steiniger, 484-485.

WILCOX, R. 1832: "Memoir of a survey of Assam and the neighbouring countries, executed in 1825-6-7-8". Asiatick Researches 17, 314-469. 